A N N A L E S

UNIVER I TATIS M A R A E C URIE-SKŁODOW S A

L UBLIN - POLONIA

VOL. LXXV

SECTIO B

2020

DAGMARA KOCIUBA

https://orcid.org/0000-0001-9217-323X

Uniwersytet Marii Curie-Skłodowskiej w Lublinie

Wydział Nauk o Ziemi i Gospodarki Przestrzennej

al. Kraśnicka 2D, 20-718 Lublin

dagmara.kociuba@umcs.pl
DOMINIKA WIELINIEC

https://orcid.org/0000-0002-4829-009X

Uniwersytet Marii Curie-Skłodowskiej w Lublinie

Wydział Nauk o Ziemi i Gospodarki Przestrzennej

al. Kraśnicka 2D, 20-718 Lublin

dominikawieliniec1@gmail.com

\title{
Rozwój infrastruktury rowerowej w kontekście działania roweru miejskiego - przykład Krakowa i Lublina
}

Development of Cycling Infrastructure in the Context of Functioning of Urban Bicycle-Sharing System - Case Study of Cracow and Lublin

\begin{abstract}
The objective of the paper is to determine the dynamics of development of urban cycling infrastructure in the context of development of bicycle-sharing systems based on the case study of Cracow and Lublin. The study particularly refers to the comparison of provisions of strategic documents with the implementation of cycling infrastructure in the years 2010-2019. It also presents, in a comprehensive way, the development of bicycle-sharing systems, and discusses the activity of informal groups and cycling organizations in both cities. The study evidenced that the expansion of infrastructure is delayed towards the provisions of strategic-programming documents, and its network is still incoherent, primarily as a result of the dispersal in urban spaces of road investments accompanied by cycling infrastructure investments. It has no effect on the development of bicycle-sharing systems, constituting a good supplementation of cycling infrastructure, as confirmed by correlation analyses. The number and location of stations, however, depend on the activities of the operator, stimulated mainly by top-bottom (Cracow) or bottom-up (Lublin) initiatives. The use of bicycle-sharing system was primarily determined by the continuity of functioning of the operator and rental cost. Despite differences in terms of the dynamics of conducted measures, the activity of cycling organizations, their spectrum, and rules of financing have an effect on both the popularisation of cycling as a means of transport, and the expansion of cycling infrastructure and bicycle-sharing systems. The best effects were obtained for the activities of the Lublin cycling ecosystem.
\end{abstract}

Keywords: bicycle-sharing system; cycling infrastructure; informal groups and cycling organizations; Lublin cycling ecosystem; Lublin; Cracow; Poland 


\begin{abstract}
Abstrakt: Celem artykułu jest identyfikacja dynamiki rozbudowy miejskiej infrastruktury rowerowej w kontekście rozwoju systemów roweru miejskiego na przykładzie Krakowa i Lublina. W szczególności odniesiono się do zagadnień dotyczących porównania zapisów dokumentów strategicznych z realizacją infrastruktury rowerowej w latach 2010-2019, a także kompleksowo przedstawiono rozwój systemów roweru miejskiego oraz omówiono działalność grup nieformalnych i organizacji rowerowych w obu miastach. Wykazano, że rozbudowa infrastruktury przebiega z opóźnieniem w stosunku do zapisów dokumentów strategiczno-programowych, a jej sieć nadal jest niespójna, co wynika głównie z rozproszenia w przestrzeni miast inwestycji drogowych, którym towarzyszą inwestycje z zakresu infrastruktury rowerowej. Nie wpływa to na rozwój systemów roweru miejskiego, które stanowią dobre uzupełnienie infrastruktury rowerowej, co potwierdziły analizy korelacji, przy czym liczba i lokalizacja stacji są uzależnione od działań operatora, stymulowanych w przewadze w ramach działań odgórnych (Kraków) lub oddolnych (Lublin). Na wykorzystanie systemów roweru publicznego wpływ miały przede wszystkim ciągłość funkcjonowania operatora i koszty wypożyczeń. Działalność organizacji rowerowych, pomimo różnic pod względem dynamiki prowadzonych działań, ich spektrum oraz zasad finansowania, ma wpływ zarówno na popularyzację transportu rowerowego, jak i na rozbudowę infrastruktury rowerowej oraz systemów roweru miejskiego. Najlepsze efekty osiągnięto w przypadku działań lubelskiego ekosystemu rowerowego.
\end{abstract}

Slowa kluczowe: rower miejski; infrastruktura rowerowa; grupy nieformalne i organizacje rowerowe; lubelski ekosystem rowerowy; Lublin; Kraków; Polska

\title{
WSTĘP
}

Nasilające się procesy urbanizacyjne oraz wzrost liczby mieszkańców na terenach miejskich wiążą się z rosnącym popytem na środki transportu, zwłaszcza indywidualnego transportu samochodowego (Urbanyi-Popiołek 2013). Powoduje to problemy związane z poruszaniem się po miastach, a także pogorszenie jakości środowiska (Gadziński 2011). Wszystko to sprawia, że w miastach wprowadzane są rozwiązania z zakresu transportu zrównoważonego (Bartniczak 2013; Przygodzki, Sokołowicz 2016), bardziej efektywnego i zmniejszającego szkodliwy wpływ pojazdów na środowisko przy równoczesnym zapewnieniu maksymalnej mobilności i ograniczeniu zużycia surowców (Pala 2013; Kauf, Szołtysek, Wieczorek 2018). Sprzyjają temu działania mające usprawnić niewydolne systemy transportowe i polepszyć jakość powietrza oraz rozładować korki, szczególnie w centrach miast, m.in. tworzenie stref z ograniczeniem ruchu samochodów (Low Emission Zones - strefy o niskiej emisji spalin; Ultra Low Emission Zones - strefy o ultra niskiej emisji spalin), zakaz wjazdu samochodów do centrów miast lub wprowadzanie opłat z tego tytułu (np. congestion charge - opłata zatłoczeniowa), obowiązujących stale lub w konkretnych dniach i godzinach (Bencekri, Kua, Kimb, Leec, Leed 2020). Służą temu również ogólnoświatowe kampanie, prowadzone m.in. w ramach Europejskiego Tygodnia Zrównoważonego Transportu 
(https://mobilityweek.eu/home), które mają na celu budowanie świadomości mieszkańców na temat alternatywnych do samochodu środków transportu.

Wynikiem tych działań jest zauważalne zainteresowanie rowerem jako środkiem transportu (DeMaio 2009). Używanie rowerów w codziennych przejazdach generuje szereg korzyści, m.in. nie wymaga zużycia paliwa, nie powoduje hałasu oraz nie wytwarza spalin, co z kolei przyczynia się do zmniejszenia emisji gazów cieplarnianych i poprawy jakości środowiska (Hitchcock, Vedrenne 2014; Zdanowska, Bojke 2017). Istotną zachętę dla mieszkańców do poruszania się jednośladem stanowią sprawne systemy infrastruktury rowerowej (Hitchcock, Vedrenne 2014) oraz ich wysoka jakość. Są to czynniki, które w dużej mierze wpływają na konkurencyjność transportu rowerowego w miastach (Rakower, Łabędzki, Gadziński 2011). Badania związane z infrastrukturą rowerową (Senetra 2010) dotyczą z jednej strony działań odgórnych związanych z jej projektowaniem i rozbudową (Górnośląski Związek Metropolitalny 2016), wspieranych niejednokrotnie z funduszy unijnych (Kociuba 2018), a także tworzenia polityk rowerowych (Ciesielski 2014). Z drugiej strony skupiają się one na analizie działań oddolnych, które znajdują odzwierciedlenie m.in. w projektach o tematyce rowerowej, zgłaszanych w ramach budżetów obywatelskich (Mroczek 2018; Kociuba, Rabczewska 2019; Kociuba, Bielecka [w druku]). Działania te skutkują rozwojem infrastruktury rowerowej w miastach.

Jednym z problemów tworzenia infrastruktury dedykowanej rowerzystom jest jej powiązanie z innymi środkami transportu w mieście (Dębowska-Mróz, Kacprzak, Zięba 2016). Rozwiązaniem w tym zakresie jest wprowadzenie systemów roweru miejskiego (DeMaio 2009; Klimkiewicz 2013). Pierwsza wypożyczalnia rowerów miejskich w Polsce powstała w 2008 r. w Krakowie (Hubka, Malinowski 2010). Od tego czasu rowery publiczne stają się coraz bardziej popularnym środkiem transportu (Łastowska, Bryniarska 2015). Obecnie w Polsce zadania związane z obsługą systemu roweru miejskiego są realizowane głównie przez trzech operatorów (BikeU, Romet Rental Systems i Nextbike), a z rowerów miejskich corocznie korzysta ponad milion osób (Dębowska-Mróz, Lis, Szymanek, Zawisza 2017). Popularyzacji wypożyczalni rowerowych sprzyja ograniczenie ruchu samochodowego i poszerzanie stref dla pieszych w centrach miast (Kłos-Adamkiewicz 2014). Wypożyczalnie miejskie mają dużo zalet. Są to m.in. konkurencyjne koszty w porównaniu z opłatą za podróżowanie transportem miejskim, poprawa wizerunku miast i zazwyczaj dobra dostępność wynikająca z lokalizacji w strategicznych miejscach w mieście (Bryniarska, Wilk 2018; Gawroński, Król, Gawrońska, Kubicki 2019). Ponadto podróżowanie rowerem jest ekologiczne, co przekłada się na jakość życia mieszkańców (Stępień-Słodkowska, Ustianowski, Krajewska-Pędzik 2017). Rozbudowa systemów roweru miejskiego znajduje odzwierciedlenie we 
wzroście natężenia ruchu rowerowego w miastach (Kopta 2010; Wolek 2010; Stowarzyszenie Akcja Miasto 2016; Buciak, Krajewska, Pawłowska 2017; Kociuba, Lubaś 2018).

Zagadnienia związane $\mathrm{z}$ transportem rowerowym są szeroko opisywane, jednakże brakuje w literaturze podejścia łączącego aspekty rozwoju infrastruktury rowerowej i rozbudowy systemów rowerów miejskich. Niniejsza praca wypełnia tę lukę badawczą. Celem artykułu jest identyfikacja dynamiki rozbudowy miejskiej infrastruktury rowerowej w kontekście rozwoju systemów roweru miejskiego. Realizacja celu opiera się na odpowiedzi na następujące pytania badawcze:

1. Czy rozbudowa infrastruktury rowerowej odbywa się zgodnie z założeniami dokumentów programowych?

2. Jak przebiegała rozbudowa systemu roweru miejskiego w Krakowie i Lublinie?

3. Czy rozwój infrastruktury rowerowej jest skorelowany z rozbudową systemów roweru miejskiego?

4. Jaki wpływ mają działania organizacji rowerowych na rozwój infrastruktury rowerowej i systemów roweru miejskiego?

Do przeprowadzenia badań szczegółowych wybrano dwa miasta - Kraków, który uważany jest za kolebkę ruchu rowerowego w Polsce, oraz Lublin, w którym liczne i unikalne w skali kraju działania oddolne znajdują wsparcie instytucjonalne ze strony miasta.

\section{INFRASTRUKTURA ROWEROWA - PODZIAŁ, STANDARDY I ZASADY PROJEKTOWANIA}

Do infrastruktury rowerowej zalicza się wiele elementów, które tworzą jeden, integralny system. Jego planowanie i realizacja odbywa się w oparciu o przepisy prawa ${ }^{1}$. Do zbioru infrastruktury liniowej należą:

- drogi rowerowe, które są oddzielone od innego ruchu. Należy je lokalizować w miejscach, gdzie konieczna jest segregacja ruchu rowerowego

\footnotetext{
1 W niniejszym artykule bazowano na zapisach: ustawy z dnia 20 czerwca 1997 r. - Prawo o ruchu drogowym (Dz.U. nr 98, poz. 602 ze zm.), rozporządzenia Ministra Transportu i Gospodarki Wodnej z dnia 2 marca 1999 r. w sprawie warunków technicznych, jakim powinny odpowiadać drogi publiczne i ich usytuowanie (Dz.U. nr 43, poz. 430), obwieszczenia Ministra Infrastruktury z dnia 9 września 2019 r. w sprawie ogłoszenia jednolitego tekstu rozporządzenia Ministra Infrastruktury w sprawie szczegółowych warunków technicznych dla znaków i sygnałów drogowych oraz urządzeń bezpieczeństwa ruchu drogowego i warunków ich umieszczania na drogach (Dz.U. 2019, poz. 2311).
} 
i samochodowego ze względu na zbyt duże prędkości². Droga rowerowa powinna być odseparowana od jezdni lub chodnika pasem zieleni, barierą, elementami małej architektury bądź betonowymi przegrodami. Drogi rowerowe to najbardziej kosztochłonny i terenochłonny element infrastruktury,

- drogi rowerowe łączone z ciągami pieszymi, oznaczone odpowiednimi znakami poziomymi,

- pasy dla rowerów wzdłuż jezdni. Są zalecane w miejscach, gdzie prędkość samochodów wynosi pomiędzy 30 a $50 \mathrm{~km} / \mathrm{h}$. Rozwiązanie to jest łatwe do stosowania na jezdniach o szerokości 9-10 m, a także przy zmianie organizacji ruchu i jego uspokojeniu na jezdniach o większej liczbie pasów ruchu w sytuacji przeznaczenia jednego $\mathrm{z}$ nich na dwa pasy rowerowe,

- ciągi pieszo-rowerowe, które stosuje się w przypadku niewystarczającej ilości miejsca dla poprowadzenia wydzielonej drogi dla rowerów,

- kontrapasy, czyli pasy rowerowe utworzone w jezdni jednokierunkowej (przy lewej krawędzi), umożliwiające rowerzystom poruszanie się „pod prąd”,

- kontraruch, dający możliwość poruszania się rowerzystów „pod prąd” na drogach jednokierunkowych z ograniczeniem prędkości do $30 \mathrm{~km} / \mathrm{h}$. Specjalny pas dla rowerzystów nie jest wówczas wyznaczony, a o występowaniu kontraruchu informują znaki drogowe. Jest to jedna z najmniej kosztochłonnych inwestycji z zakresu infrastruktury rowerowej,

- śluzy dla rowerzystów, czyli część jezdni na wlocie skrzyżowania, na całej szerokości jezdni lub wybranego pasa ruchu, przeznaczona do zatrzymania rowerów w celu zmiany kierunku jazdy lub ustąpienia pierwszeństwa,

- łączniki dla rowerzystów.

Dodatkowymi elementami uzupełniającymi infrastrukturę liniową są urządzenia oraz punkty, które wspomagają ruch rowerowy, np. miejsca obsługi rowerzystów (MOR), parkingi, stacje naprawcze, podpórki dla rowerzystów w obrębie skrzyżowań oraz stojaki na rowery (Dąbrowska-Loranc i in. 2019).

Kluczowym elementem infrastruktury rowerowej są drogi dla rowerów. Można je podzielić na trzy klasy (Beim i in. 2015). Są to:

- drogi główne, które łączą obszary centrów miast z obszarami podmiejskimi, a także miejsca pełniące ważne funkcje w mieście, np. administracyjne, kulturalne, edukacyjne, usługowe. Infrastruktura tras głównych powinna mieć najwyższe standardy oraz zapewniać szybkie poruszanie się na danym odcinku. Parametry dróg głównych powinny umożliwiać poruszanie się dwóch osób w jednym kierunku,

2 Niebezpieczne prędkości to te powyżej $30 \mathrm{~km} / \mathrm{h}$ dla ruchu samochodowego z dopuszczeniem transportu ciężkiego bądź $50 \mathrm{~km} / \mathrm{h}$ dla ruchu samochodów osobowych. 
- drogi pomocnicze służące jako łączniki prowadzące do pozostałych kategorii tras, tj. głównych i turystycznych. Można je wyznaczać na elementach infrastruktury rowerowej oraz na odcinkach dróg, które zapewniają bezpieczne użytkowanie przez rowerzystów,

- drogi rekreacyjne lub turystyczne, głównie zlokalizowane poza obszarem zabudowanym. Powinny obejmować proste i dłuższe odcinki dróg. W przestrzeni miejskiej trasy mogą prowadzić do obszarów rekreacyjnych, np. do boiska, parku.

Aby odpowiednio dobrać standardy dla realizacji drogi rowerowej, należy rozpoznać (Kociuba, Lubaś 2018):

- główne kierunki podróży,

- intensywność podróży (liczba użytkowników w określonym czasie),

- miejsca, gdzie można zainstalować infrastrukturę rowerową (np. parkingi rowerowe).

W myśl obowiązujących przepisów infrastruktura rowerowa powinna spełniać określone standardy. Dotyczą one głównie parametrów i warunków technicznych ich umieszczania na drogach, lokalizacji w stosunku do innych elementów infrastruktury drogowej czy właściwego oznaczenia. Przykładowo ścieżki rowerowe na drogach klas G (główna), Z (zbiorcza), L (lokalna) i D (dojazdowa) powinny mieć szerokość $1,5 \mathrm{~m}$ przy ruchu jednokierunkowym, $2 \mathrm{~m}$ przy ruchu dwukierunkowym, a 2,5 m wtedy, gdy ze ścieżki jednokierunkowej mogą korzystać piesi; ich pochylenie podłużne nie powinno przekraczać 5\% (w wyjątkowych przypadkach 15\%), a poprzeczne - ze względu na lepszy spływ wód opadowych - może wynosić od 1\% do 3\%. Pomiędzy ścieżką rowerową a innymi pasami ruchu należy zastosować wyspę dzielącą lub znaki poziome, które zwiększają czytelność przeznaczenia. Wysokość skrajni (wolna przestrzeń, która umożliwia prowadzenie ruchu, zatrzymanie lub postój) nie może być mniejsza niż $2,5 \mathrm{~m}$ (przy czym dopuszcza się 2,2 m, np. podczas remontu lub przebudowy dróg).

Oznakowanie dróg dla rowerów powinno być widoczne i odróżniać się od innych oznaczeń drogowych. Poszczególne elementy infrastruktury rowerowej oznaczone są znakami:

- pionowymi, wśród których wyróżnia się: ostrzegawcze, zakazu, nakazu, informacyjne, uzupełniające oraz tabliczki. Mają one za zadanie ostrzegać użytkowników o miejscach wymagających szczególnej ostrożności oraz miejscach niebezpiecznych. Do najczęściej stosowanych znaków pionowych zalicza się: A-24 - rowerzyści, B-9 - zakaz wjazdu rowerów, C-13 - droga dla rowerów, C-13a - koniec drogi dla rowerów, C-13/16 - droga dla rowerów i pieszych,

- poziomymi, do których zalicza się linie segregacyjne oraz strzałki kierunkowe. Zasadniczym celem wprowadzenia linii segregacyjnych jest oddzielenie od siebie pasów ruchu, które biegną w tym samym lub przeciwnym kierunku, 
a także informowanie użytkowników o miejscach możliwych do przekroczenia. Znakami dopełniającymi oznaczenia poziome są: P-15, P-16, P-19, P-23, P-27, - uzupełniającymi, które informują o organizacji ruchu oraz uprzedzają o zakazach i niebezpieczeństwach. Są one umieszczane pod znakami pionowymi (np. C-1 do C-10, B-1, B-2, B-21 oraz D-3) i wskazują, że dany zakaz lub nakaz nie dotyczy rowerów. Zalicza się tu głównie znak F-19 (pas ruchu dla określonych pojazdów) oraz tabliczkę T-22 (nie dotyczy rowerów).

Istotnym elementem organizującym ruch rowerowy jest sygnalizacja drogowa. Specjalnie dedykowane dla rowerzystów sygnalizatory (S-1a, S-3a) mają na swojej tarczy czarny symbol roweru i stosowane są na jezdniach z wyznaczonym pasem ruchu dla rowerów oraz śluz dla rowerów.

Projektowanie infrastruktury rowerowej powinno być procesem wieloaspektowym i integralnym ze wszystkimi środkami transportu. Infrastruktura musi spełniać wszelkie wymogi wynikające $\mathrm{z}$ aktów prawnych oraz być bezpieczna dla użytkowników. Przy projektowaniu infrastruktury rowerowej powinno się wykorzystywać również zasady, które zostały sformułowane przez holenderską organizację C.R.O.W. (Postaw na rower... 1999). Należą do nich:

1. Spójność infrastruktury z innymi odcinkami dróg oraz źródłami i celami podróży rowerowych. Dzięki temu osoba wybierająca rower jako środek transportu ma pewność, że dotrze do celu bez większych niedogodności.

2. Bezpośredniość. Ma na celu zmniejszenie odległości pomiędzy punktami docelowymi. Trasy powinny być optymalnie jak najkrótsze, aby umożliwić jak najszybsze dotarcie do celu.

3. Atrakcyjność. Wiąże się z istotnymi elementami zagospodarowania przestrzennego i dostosowania przebiegu trasy rowerowej do terenów otaczających pasy ruchu dla rowerzystów. O atrakcyjności decyduje głównie zieleń, czytelność trasy oraz przyjazne otoczenie.

4. Bezpieczeństwo w ruchu drogowym zarówno rowerzystów, jak i innych użytkowników dróg. Jest ono realizowane poprzez: oddzielenie ruchu rowerowego od innych rodzajów ruchu przy prędkości powyżej $50 \mathrm{~km} / \mathrm{h}$, wprowadzenie właściwej szerokości dróg oraz oznakowania skrzyżowań, dobrą widoczność, oświetlenie. Należy prowadzić ruch rowerowy jedną stroną jezdni, a w sytuacji przenoszenia go na drugą stronę powinno się przeprowadzić go w miejscu dobrze oznaczonym i widocznym dla innych uczestników ruchu drogowego.

5. Wygoda. Umożliwia szybki i wygodny przepływ ruchu rowerów. Czynnikami warunkującymi wygodę infrastruktury są: równa nawierzchnia, nieznaczne pochylenie podłużne terenu (do 6\%), płynność trasy poprzez zmniejszenie lub wyeliminowanie utrudnień powodujących niepotrzebne manewry, w tym hamowanie lub zatrzymanie (m.in. wysokich krawężników, słupków, koszy na śmieci, 
zaparkowanych samochodów). Wpływają one zarówno na jakość podróży, jak i na komfort psychiczny rowerzysty.

Poprawne projektowanie infrastruktury rowerowej powinno dążyć do konkretnych celów. Jednym z nich jest zmniejszenie zatłoczenia na drogach i zachęcanie użytkowników do wybierania ekologicznych środków transportu. Należy promować transport rowerowy nawet na krótkich odcinkach.

\section{OBSZAR BADAŃ}

Kraków oraz Lublin to jedne z najstarszych miast Polski o bogatej historii, szczególnych walorach turystycznych i rekreacyjnych, a także o urozmaiconej rzeźbie terenu.

Kraków - dawna stolica Polski, obecnie zaś jedno z najbardziej rozpoznawanych miast na świecie - liczy 779 tys. mieszkańców, a jego powierzchnia wynosi $327 \mathrm{~km}^{2}$. Kraków podzielony jest na 18 dzielnic (ryc. 1). Jako jedno z nielicznych miast w Polsce cechuje się dodatnim saldem migracji i jedną z najniższych wartości stopy bezrobocia (2,3\%). Ponadto jest jednym z największych ośrodków akademickich. Funkcjonuje tu 21 uczelni (m.in. Uniwersytet Jagielloński, Akademia Górniczo-Hutnicza im. Stanisława Staszica, Politechnika Krakowska im. Tadeusza Kościuszki) oraz 5 jednostek zamiejscowych. W roku akademickim 2018/2019 studiowało tu 135 tys. osób (Urząd Statystyczny w Krakowie 2019).

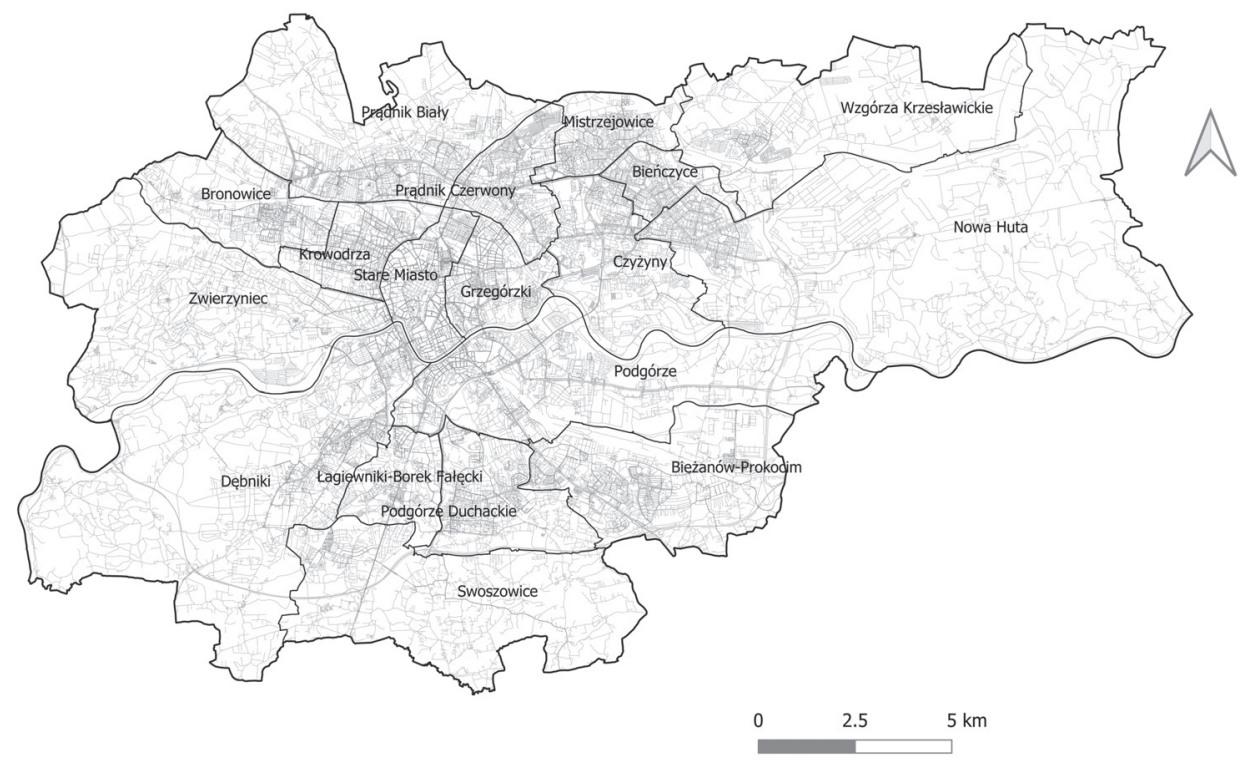

Ryc. 1. Podział administracyjny Krakowa (opracowanie własne)

Fig. 1. Administrative division of Cracow (own elaboration) 
Lublin jest stolicą województwa lubelskiego, znajdującego się we wschodniej Polsce. Miasto liczy 340 tys. mieszkańców, a jego powierzchnia wynosi $147 \mathrm{~km}^{2}$. Lublin jest podzielony na 27 dzielnic (ryc. 2). Miasto cechuje się ujemnym saldem migracji oraz stopą bezrobocia na poziomie 5,5\%. Lublin jest największym ośrodkiem akademickim we wschodniej Polsce. Na terenie miasta znajduje się 9 uczelni wyższych (m.in. Uniwersytet Marii Curie-Skłodowskiej, Katolicki Uniwersytet Lubelski, Politechnika Lubelska, Uniwersytet Przyrodniczy, Uniwersytet Medyczny), w których w roku akademickim 2018/2019

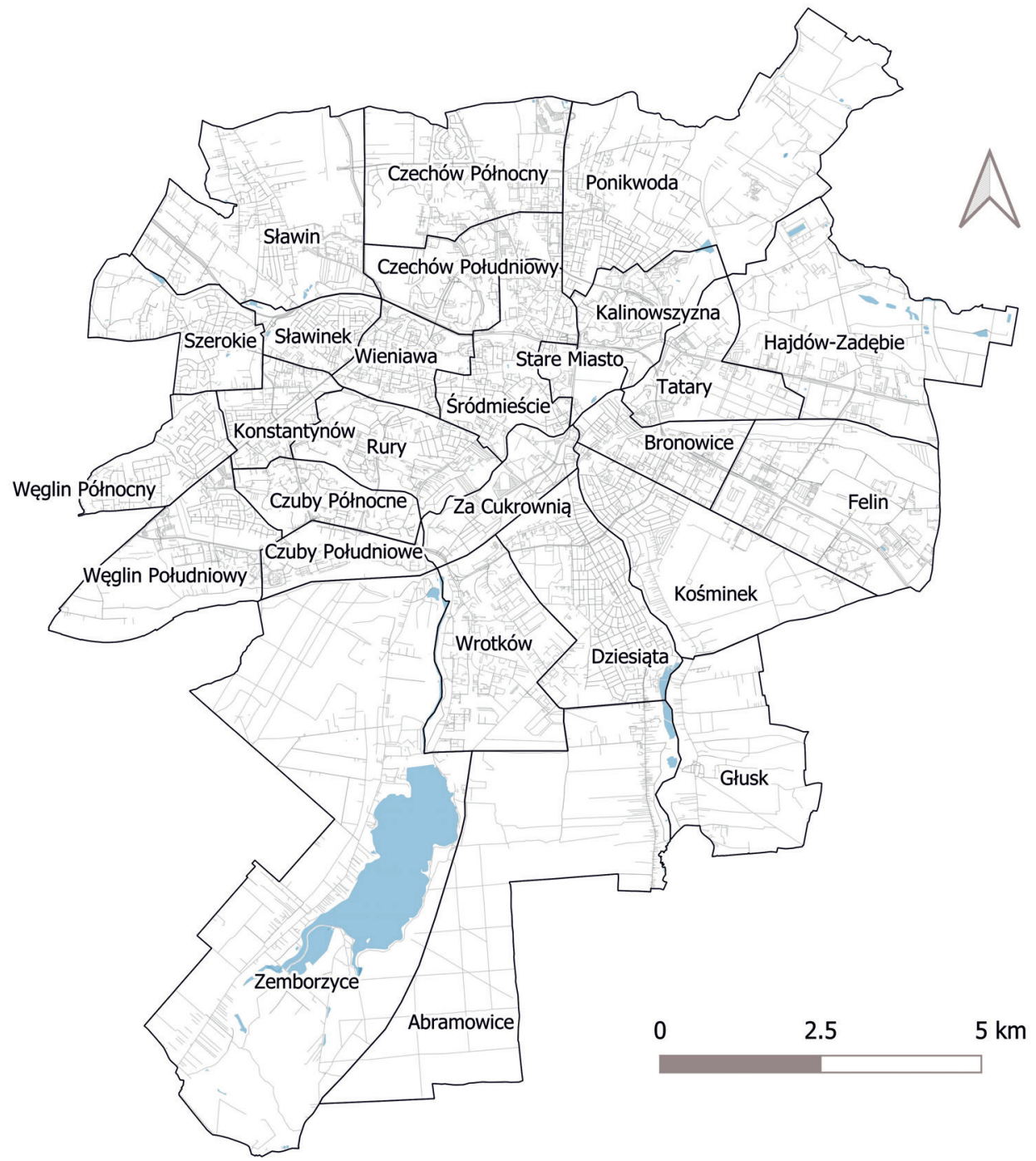

Ryc. 2. Podział administracyjny Lublina (opracowanie własne)

Fig. 2. Administrative division of Lublin (own elaboration) 
kształciło się 61 tys. studentów. Lublin ma też najwyższy w Polsce wskaźnik umiędzynarodowienia, który wynosi $10 \%$.

\section{MATERIAŁY I METODY}

Opracowując zagadnienia teoretyczne związane z projektowaniem infrastruktury rowerowej oraz organizacją ruchu rowerowego, bazowano na aktach prawnych (zob. akty prawne w bibliografii) oraz opracowaniach specjalistycznych (m.in. przygotowanych przez C.R.O.W.). Dane dotyczące infrastruktury rowerowej zostały pozyskane z Raportów Stanu Miasta (http://bip.krakow.pl/?mmi=509), dokumentów związanych z wykonaniem budżetu (http://lublin.eu/finanse-i-majatek/sprawozdanie-z-wykonania-budzetu-miasta) oraz opracowań przygotowanych przez grupy aktywistów (http://ibikekrakow.com/mapa; http:// mirl.info.pl/mapa). Zapisy dokumentów strategiczno-programowych, tj. Studium Sieci Tras Rowerowych wraz z Programem Inwestycji - Studium Podstawowych Tras Rowerowych (2010) oraz Strategii realizacji systemu dróg rowerowych w mieście Lublin wraz z oceną oddziaływania na środowisko (2014), posłużyły jako baza dla dokonania porównań stanu aktualnego z przyjętymi przez miasta założeniami dotyczącymi rozbudowy infrastruktury rowerowej.

Kluczowe dane związane z funkcjonowaniem systemów rowerów publicznych w Krakowie i Lublinie zostały udostępnione przez operatorów Wavelo oraz Lubelskiego Roweru Miejskiego (LRM), a także pozyskane z baz danych opracowywanych przez lubelskie środowiska rowerowe (https://mirl.info.pl/publications) oraz ze stron internetowych Zarządu Transportu Publicznego w Krakowie (http://rowery.zikit.pl). Aby ocenić jakość infrastruktury rowerowej i zgodność jej wykonania $\mathrm{z}$ wytycznymi ministerialnymi i standardami, przeprowadzono inwentaryzację istniejących dróg rowerowych w Krakowie i Lublinie.

Do badań siły związku pomiędzy rozbudową infrastruktury rowerowej i rozwojem systemów roweru miejskiego posłużył wskaźnik korelacji liniowej r-Pearsona:

$$
r=\frac{\sum_{i}\left(x_{i}-\bar{x}\right)\left(y_{i}-\bar{y}\right)}{\sqrt{\sum_{i}\left(x_{i}-\bar{x}\right)^{2}} \sqrt{\sum_{i}\left(y_{i}-y\right)^{2}}}
$$

Dane zostały podzielone na dwie kategorie: infrastrukturalne (długość oraz gęstość dróg rowerowych ogółem, w tym pasów rowerowych oraz kontrapasów i kontraruchu) oraz związane z działaniem systemów roweru miejskiego (liczba stacji, rowerów, użytkowników i wypożyczeń). Analizie poddano dane z lat 2016-2019. 
Wyniki analiz przedstawiono na rycinach i w tabelach. W pracy zamieszczono również materiały graficzne opracowane przez lubelskie organizacje rowerowe, dotyczące wykorzystania stacji LRM (m.in. za pomocą więźby ruchu i map ciepła).

\section{ROZWÓJ INFRASTRUKTURY ROWEROWEJ A DZIAŁANIE ROWERU MIEJSKIEGO W KRAKOWIE}

\section{Zapisy dokumentów strategiczno-programowych a realizacja infrastruktury rowerowej w Krakowie}

Jednym z pierwszych dokumentów dotyczących transportu oraz zagadnień z zakresu ruchu rowerowego w Polsce była Polityka transportowa dla Krakowa, uchwalona w 1993 r. (Uchwała nr LXX/468/93). Zawarto w niej zapisy dotyczące ruchu rowerowego, m.in. bezpieczeństwa rowerzystów na drogach, zwiększenia udziału rowerzystów w ogóle podróży do 5-10\% oraz realizacji budowy ok. 200 km ścieżek rowerowych. Od początku lat 2000. rozbudowa infrastruktury rowerowej stała się też jednym z priorytetów polityki przestrzennej i transportowej Krakowa. W 2003 r. zostało uchwalone Studium kierunków i uwarunkowań zagospodarowania przestrzennego, w którym uwzględniono ruch rowerowy, a także został powołany zespół zadaniowy do spraw ścieżek rowerowych. W tym samym roku powstało

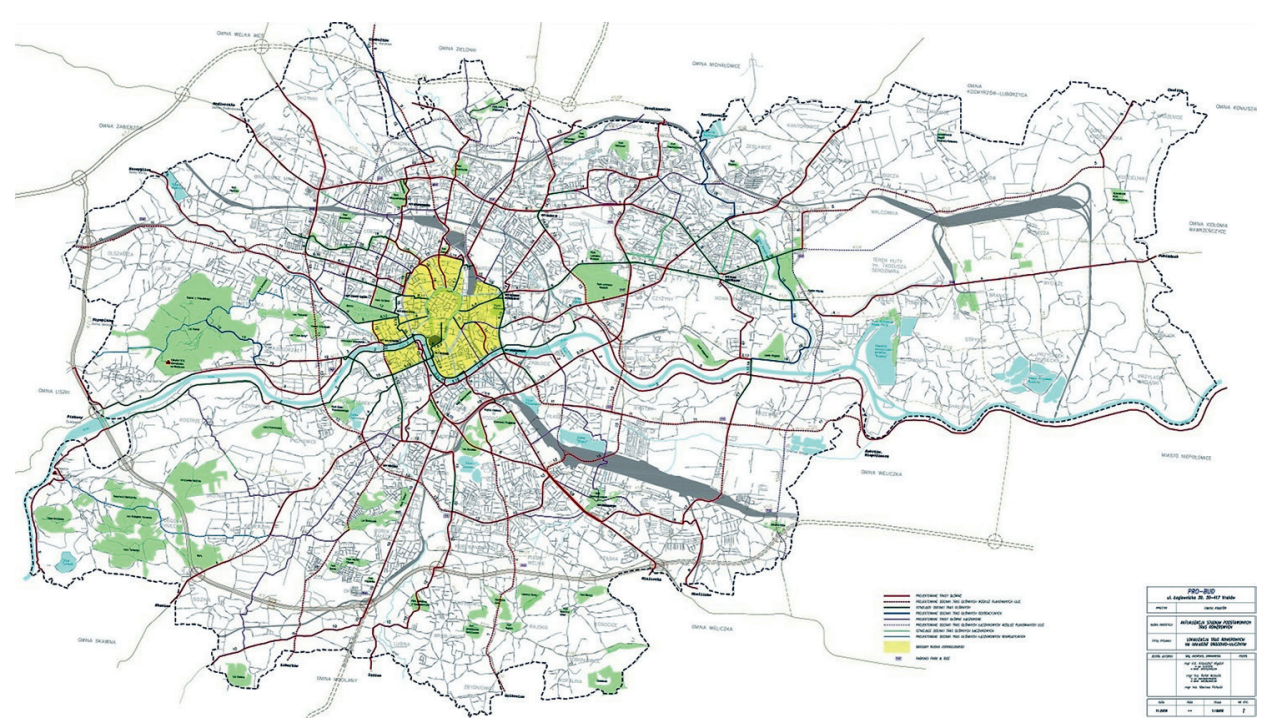

Ryc. 3. Planowany przebieg tras rowerowych w Krakowie w 2015 r. (na podstawie Studium Sieci Tras Rowerowych 2010)

Fig. 3. Planned course of bicycle routes in Cracow in 2015 (based on the Study of the Cycle Route Network 2010) 
Studium Sieci Tras Rowerowych. Projektowanie infrastruktury drogowej dla rowerzystów opiera się na wytycznych zawartych w Standardach technicznych dla infrastruktury rowerowej m. Krakowa (2004). Dokument zaktualizowano w 2018 r. (Zarządzenie nr 3113/2018). Obecnie w Krakowie obowiązuje Polityka transportowa dla Miasta Krakowa na lata 2016-2025 (Uchwała nr XLVII/848/16). Dokument przewiduje rozbudowę infrastruktury rowerowej, rozwój systemu rowerów publicznych (powiększenie liczby stacji i rowerów) oraz wprowadzenie dodatkowych stref ruchu uspokojonego. Kierunki rozbudowy infrastruktury rowerowej określa Studium Sieci Tras Rowerowych wraz z Programem Inwestycji - Studium Podstawowych Tras Rowerowych (Uchwała nr CIX/1493/10). W Programie Inwestycji wyznaczono 19 tras rowerowych. Założono, że w mieście w latach 2010-2015 powstanie łącznie $223,11 \mathrm{~km}$ infrastruktury rowerowej (ryc. 3). Rozbudowę infrastruktury rowerowej w Krakowie opisano w tab. 1.

Tab. 1. Rozbudowa infrastruktury rowerowej w Krakowie w latach 2010-2019 (opracowanie własne) Table 1. Expansion of bicycle infrastructure in Cracow 2010-2019 (own elaboration)

\begin{tabular}{|c|c|c|}
\hline \multicolumn{2}{|c|}{$\begin{array}{l}\text { Długość infrastruktury } \\
\text { w km }\end{array}$} & Opis działań \\
\hline 2010 & 89,00 & \multirow{3}{*}{$\begin{array}{l}\text { Drogi rowerowe znajdowały się głównie w północno-wschodniej } \\
\text { oraz centralnej części miasta }\end{array}$} \\
\hline pasy rowerowe & - & \\
\hline kontraruch & 5,56 & \\
\hline 2011 & 99,80 & \multirow{3}{*}{$\begin{array}{l}\text { Nowe odcinki dróg rowerowych }(10,8 \mathrm{~km}) \text { powstały w dziel- } \\
\text { nicach Podgórze Duchackie (ul. Christo Botewa, ul. Herberta) } \\
\text { i Łagiewniki-Borek Fałęcki (ul. Do Sanktuarium). Na Starym } \\
\text { Mieście wprowadzono pierwszy kontrapas (ul. Szlak) o długości } \\
1,1 \mathrm{~km}\end{array}$} \\
\hline pasy rowerowe & - & \\
\hline kontraruch & 6,60 & \\
\hline 2012 & 113,40 & \multirow{3}{*}{ Powstało $11,8 \mathrm{~km}$ dróg rowerowych oraz $1,8 \mathrm{~km}$ kontraruchu } \\
\hline pasy rowerowe & - & \\
\hline kontraruch & 8,40 & \\
\hline 2013 & 125,20 & \multirow{3}{*}{$\begin{array}{l}\text { Powstało 10,6 km dróg rowerowych. Kontrapasy wyznaczo- } \\
\text { no w dzielnicach Podgórze (ul. Grochowa) i Stare Miasto (ul. } \\
\text { Łobzdowska), a kontraruch - w dzielnicach Prądnik Biały (ul. } \\
\text { Kluczborska) i Stare Miasto (ul. Bożego Ciała) }\end{array}$} \\
\hline pasy rowerowe & - & \\
\hline kontraruch & 9,60 & \\
\hline 2014 & 137,00 & \multirow{3}{*}{$\begin{array}{l}\text { Powstało } 8,9 \mathrm{~km} \text { dróg rowerowych oraz został poprowadzony pas } \\
\text { rowerowy o długości } 0,35 \mathrm{~km} \text { na ul. Piastowskiej. Wyznaczono } \\
\text { kontrapasy na } 14 \text { ulicach w obrębie centrum Krakowa* o łącznej } \\
\text { długości ok. } 2,9 \mathrm{~km}\end{array}$} \\
\hline pasy rowerowe & 0,35 & \\
\hline kontraruch & 12,50 & \\
\hline 2015 & 144,50 & \multirow{3}{*}{$\begin{array}{l}\text { Powstało } 1,9 \text { km dróg rowerowych oraz 5,6 km kontraruchu. } \\
\text { Ruch rowerowy pod prąd został dopuszczony na } 65 \text { ulicach } \\
\text { w mieście. Ponadto w latach 2014-2015 ustawiono } 1600 \text { stoja- } \\
\text { ków rowerowych }\end{array}$} \\
\hline pasy rowerowe & 0,35 & \\
\hline kontraruch & 18,10 & \\
\hline
\end{tabular}




\begin{tabular}{|c|c|c|}
\hline 2016 & 166,80 & \multirow{3}{*}{$\begin{array}{l}\text { Powstało } 9,9 \mathrm{~km} \text { dróg rowerowych oraz dopuszczono do ruchu } \\
\text { rowerzystów pod prąd na } 37 \text { ulicach jednokierunkowych o łącz- } \\
\text { nej długości } 12,2 \mathrm{~km} \text {. Zamontowano } 50 \text { podpórek rowerowych. } \\
\text { Miasto sfinansowało zakup ok. } 800 \text { U-kształtnych stojaków } \\
\text { rowerowych, a przy Dworcu Głównym zlokalizowano pierwszy } \\
\text { dwupiętrowy stojak rowerowy na } 38 \text { rowerów }\end{array}$} \\
\hline pasy rowerowe & 0,35 & \\
\hline kontraruch & 30,50 & \\
\hline 2017 & 202,60 & \multirow{3}{*}{$\begin{array}{l}\text { Ruch rowerowy pod prąd został dopuszczony na ponad } 110 \\
\text { ulicach jednokierunkowych o łącznej długości } 26 \mathrm{~km} \text {. Dodat- } \\
\text { kowo w mieście umieszczono ok. } 1500 \text { U-kształtnych stojaków } \\
\text { rowerowych }\end{array}$} \\
\hline pasy rowerowe & 2,90 & \\
\hline kontraruch & 56,70 & \\
\hline 2018 & 215,70 & \multirow{3}{*}{$\begin{array}{l}\text { Miasto wybudowało ponad 9,3 km infrastruktury rowerowej. } \\
\text { Na } 19 \text { ulicach jednokierunkowych w obrębie centrum został } \\
\text { dopuszczony ruch rowerowy dwukierunkowy. W ramach budżetu } \\
\text { obywatelskiego na obszarze Dzielnicy VIII zamontowano } 21 \\
\text { samoobsługowych stacji napraw rowerów }\end{array}$} \\
\hline pasy rowerowe & 2,90 & \\
\hline kontraruch & 60,10 & \\
\hline 2019 & 223,00 & \multirow{3}{*}{$\begin{array}{l}\text { Powstało ok. } 13 \mathrm{~km} \text { ścieżek rowerowych, z czego } 8,6 \mathrm{~km} \text { stano- } \\
\text { wiły ciągi pieszo-rowerowe, a } 4,4 \mathrm{~km} \text { to drogi dla rowerów }\end{array}$} \\
\hline pasy rowerowe & 2,90 & \\
\hline kontraruch & 67,90 & \\
\hline
\end{tabular}

* były to ulice: Szpitalna, Józefińska, Garncarska, Szlak, Staromostowa, Smolki, Siedleckiego, Senatorska, Racławicka, Powiśle, Przy Moście, Miodowa, Podzamcze oraz Augustiańska

W 2010 r. długość infrastruktury liczyła 89 km i była zlokalizowana głównie w północno-wschodniej oraz centralnej części miasta (ryc. 4). W ciągu ostatnich 10 lat wybudowano lub wyznaczono 134 km dróg i ścieżek rowerowych (w tym

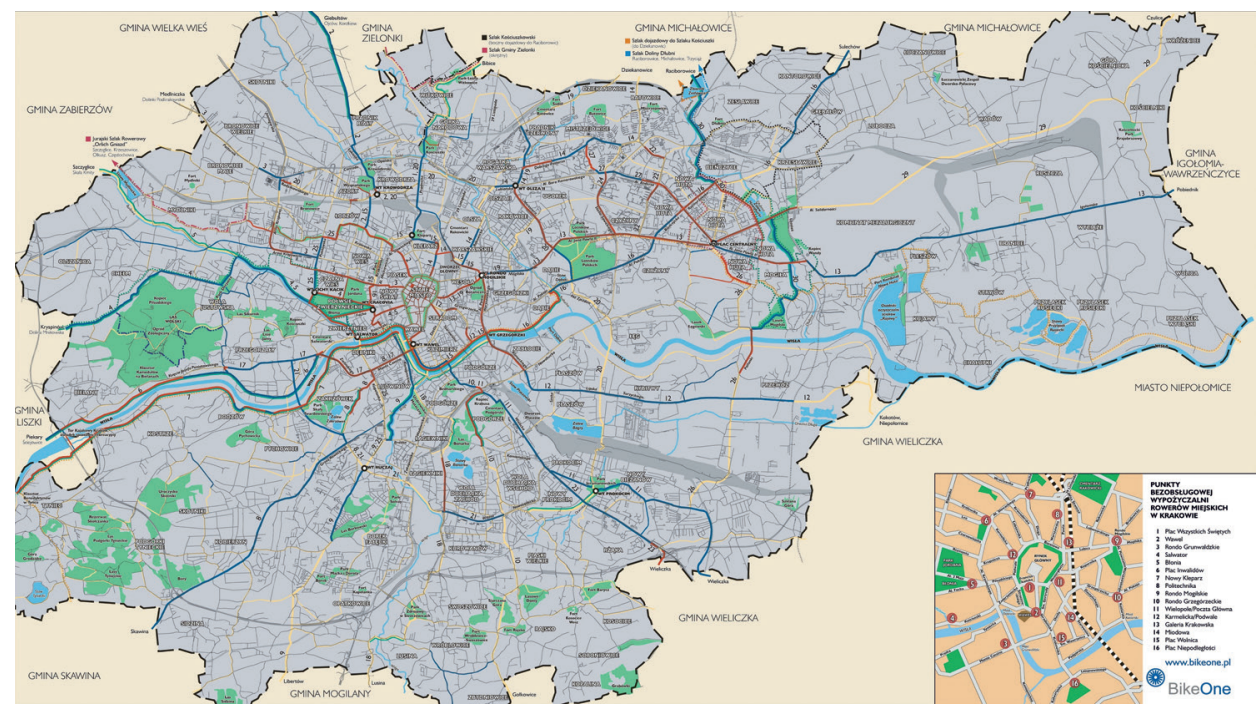

Ryc. 4. Rozmieszczenie infrastruktury rowerowej w Krakowie w 2010 r. (na podstawie Eko Edu Bike Map Kraków)

Fig. 4. Location of the bicycle infrastructure in Cracow in 2010 (based on the Eko Edu Bike Map Cracow) 
$30 \%$ obejmuje kontraruch). Przyrost infrastruktury był początkowo niewielki (ok. $10 \mathrm{~km}$ rocznie) i obejmował głównie centralne dzielnice miasta. Znaczące wzrosty odnotowano w latach 2016-2017 (58 km, z tego $39 \mathrm{~km} \mathrm{w}$ ramach kontraruchu), co było związane z jednej strony z wprowadzaniem ułatwień dla osób korzystających z rowerów w codziennych podróżach w Strefie Płatnego Parkowania w centrum miasta (w 2017 r. na ponad 200 ulicach obowiązywał kontraruch), z drugiej zaś z realizacją projektów finansowanych w ramach Zintegrowanych Inwestycji Terytorialnych oraz zadań inwestycyjnych miasta. W 2019 r. długość sieci (ulice z kontraruchem, kontrapasami i pasami rowerowymi) wynosiła $223 \mathrm{~km}$, tj. tyle, ile założono na 2015 r. Najgęstsza była w centralnej części miasta (ryc. 5).

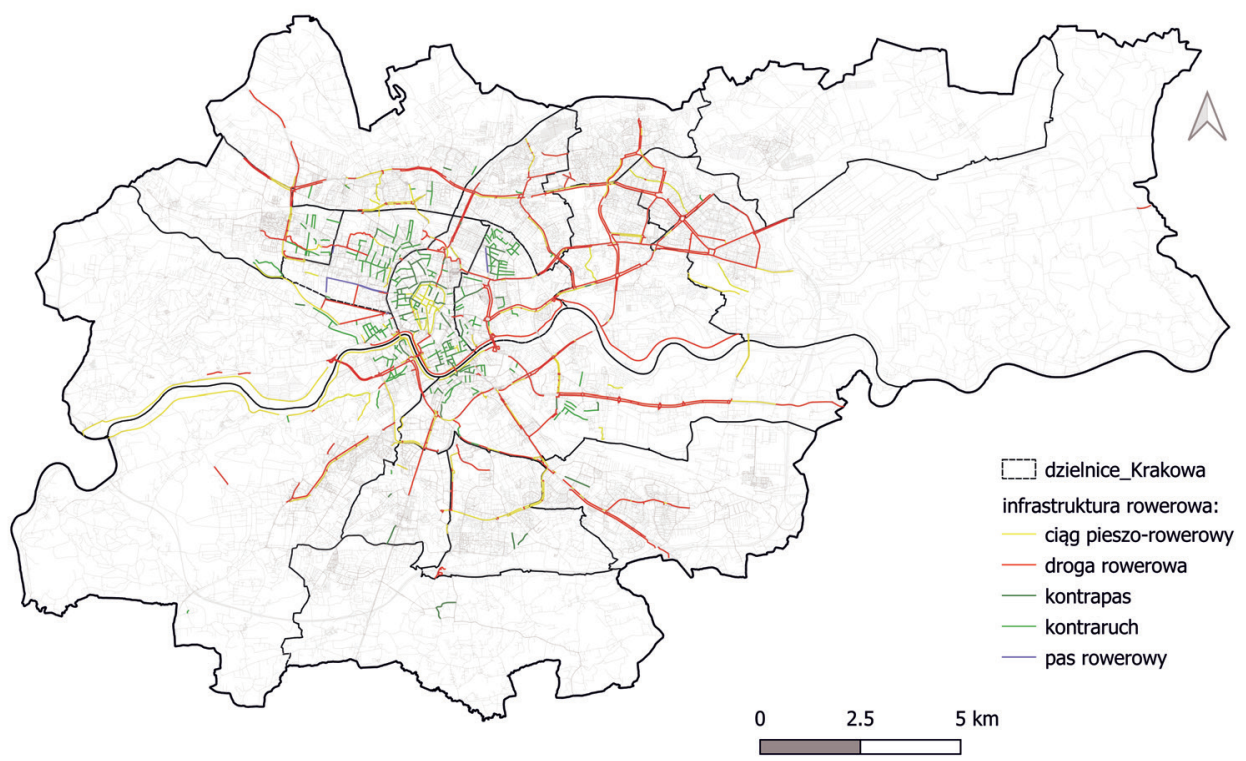

Ryc. 5. Rozmieszczenie infrastruktury rowerowej w Krakowie w 2019 r. (opracowanie własne) Fig. 5. Location of the bicycle infrastructure in Cracow in 2019 (own elaboration)

Odnosząc się do zapisów Studium Sieci Tras Rowerowych (2010) należy podkreślić, że nadal nie zrealizowano poszczególnych odcinków infrastruktury rowerowej na terenie Starego Miasta w obrębie ulic: Starowiślnej, al. Daszyńskiego, Brodowicza, Olszyny, al. Słowackiego, Długiej, Czarnowiejskiej i Miechowskiej (ryc. 6). W zachodniej części miasta nadal nie zostały zrealizowane odcinki infrastruktury rowerowej na ulicach: Pasternik, Księcia Józefa, Bunscha, Skotnickiej i Oleandry (ryc. 7). W północnej części miasta dotychczas nie zrealizowano dróg rowerowych w dzielnicach Prądnik Biały i Prądnik Czerwony na ulicach: 


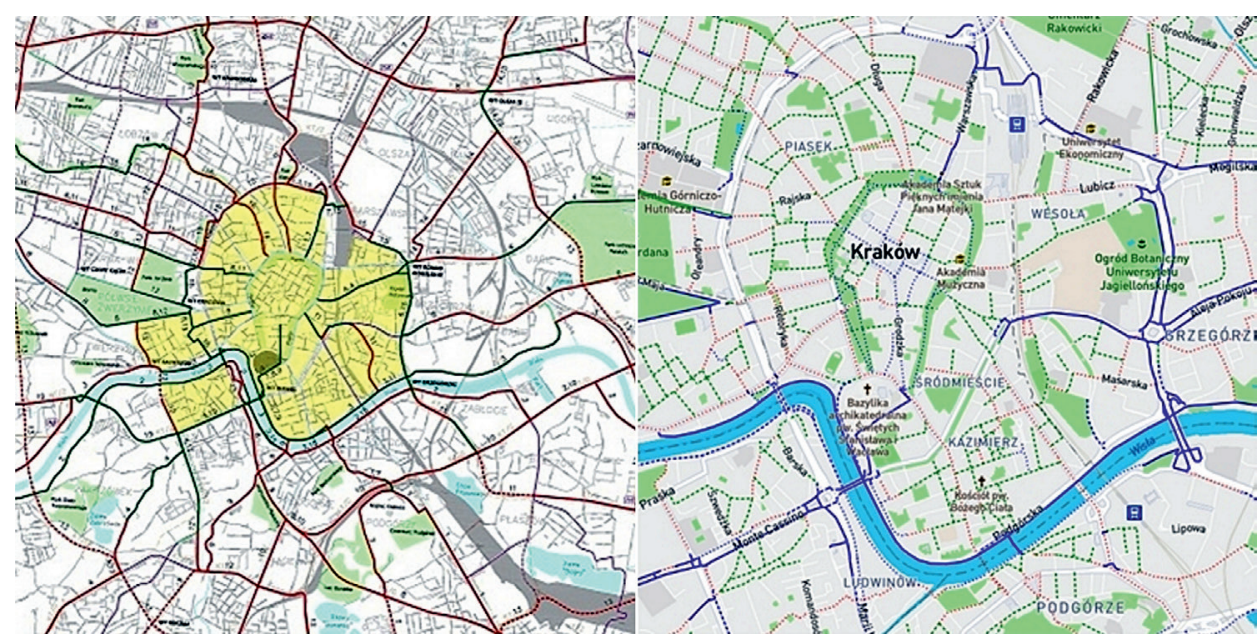

Ryc. 6. Planowane w Studium Sieci Tras Rowerowych (2010) i zrealizowane do 2019 r. odcinki infrastruktury rowerowej na Starym Mieście w Krakowie (opracowanie własne)

Fig. 6. Cycling road system sections planned in the Study of the Cycle Route Network (2010) and completed by 2019 in the Old Town of Cracow (own elaboration)

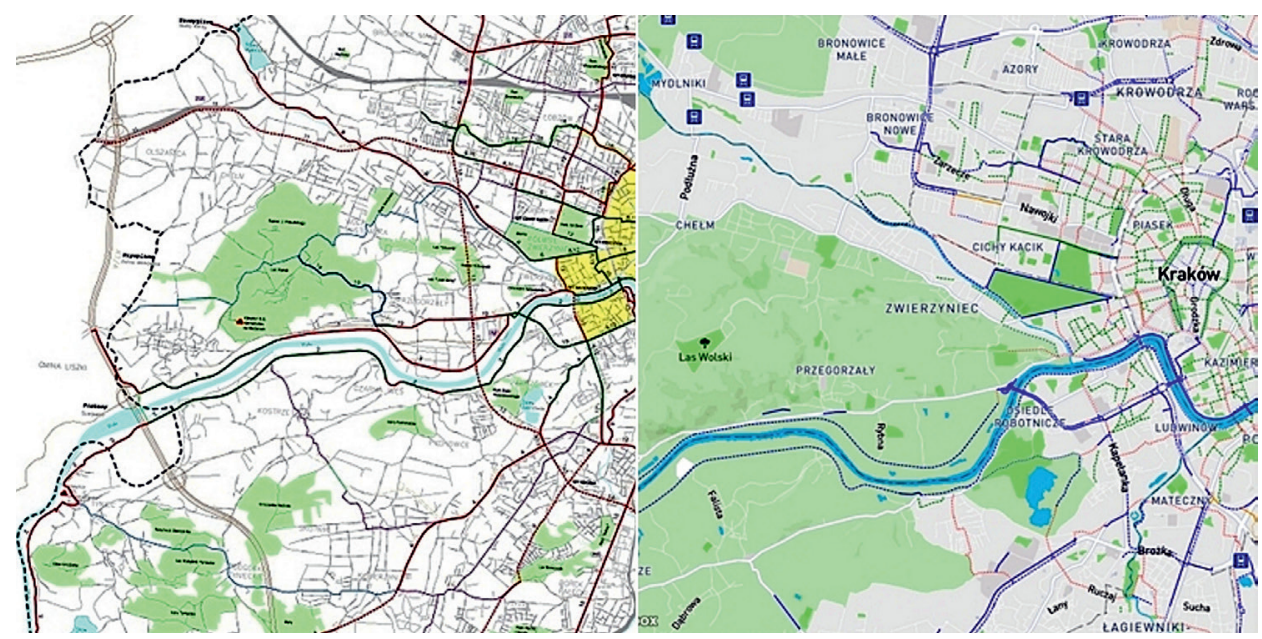

Ryc. 7. Planowane w Studium Sieci Tras Rowerowych (2010) i zrealizowane do 2019 r. odcinki infrastruktury rowerowej w zachodniej części Krakowa (opracowanie własne)

Fig. 7. Cycling road system sections planned in the Study of the Cycle Route Network (2010) and completed by 2019 in the western part of Cracow (own elaboration)

Mackiewicza, Batalionu „Skała” AK, Władysława Łokietka, al. 29 Listopada, Pachońskiego (ryc. 8). W południowej części miasta nie zostały zbudowane odcinki w obrębie ulic: Herberta, Zakopiańskiej, Taklińskiego, Smoleńskiego, Obozowej, Zawiłej, Grota-Roweckiego (ryc. 9). Tylko we wschodniej części miasta zapisy dotyczące infrastruktury rowerowej zostały w pełni zrealizowane. Drogi 


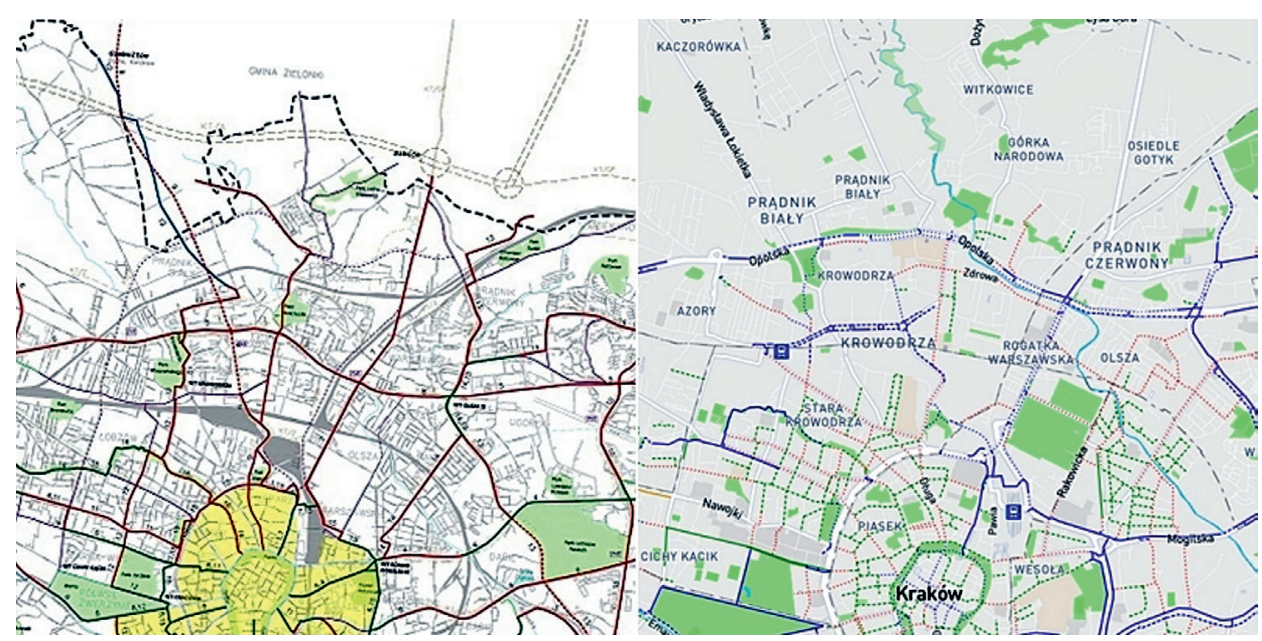

Ryc. 8. Planowane w Studium Sieci Tras Rowerowych (2010) i zrealizowane do 2019 r. odcinki infrastruktury rowerowej w północnej części Krakowa (opracowanie własne)

Fig. 8. Cycling road system sections planned in the Study of the Cycle Route Network (2010) and completed by 2019 in the northern part of Cracow (own elaboration)

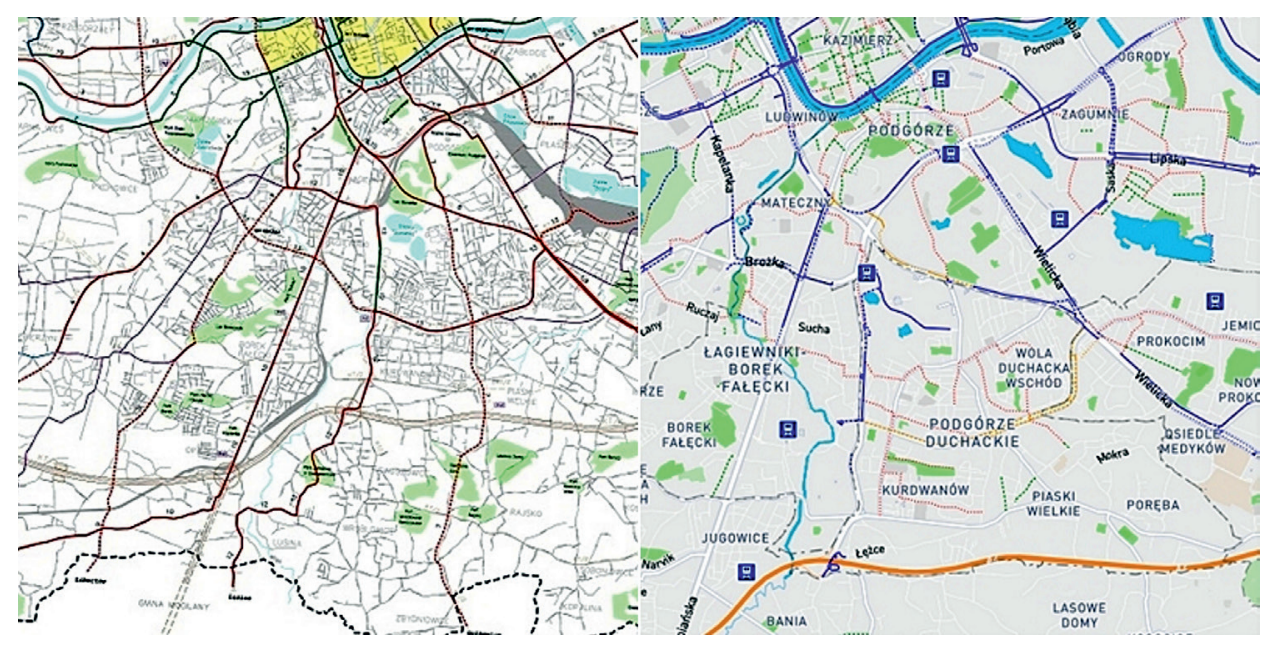

Ryc. 9. Planowane w Studium Sieci Tras Rowerowych (2010) i zrealizowane do 2019 r. odcinki infrastruktury rowerowej w południowej części Krakowa (opracowanie własne)

Fig. 9. Cycling road system sections planned in the Study of the Cycle Route Network (2010) and completed by 2019 in the southern part of Cracow (own elaboration)

rowerowe zlokalizowane są przy wszystkich drogach głównych (ryc. 10). Należy dodać, że zarówno w zachodniej, jak i we wschodniej części miasta występują rozległe tereny zielone, przez co sieć dróg rowerowych jest tu rzadsza niż na terenach zainwestowanych. 


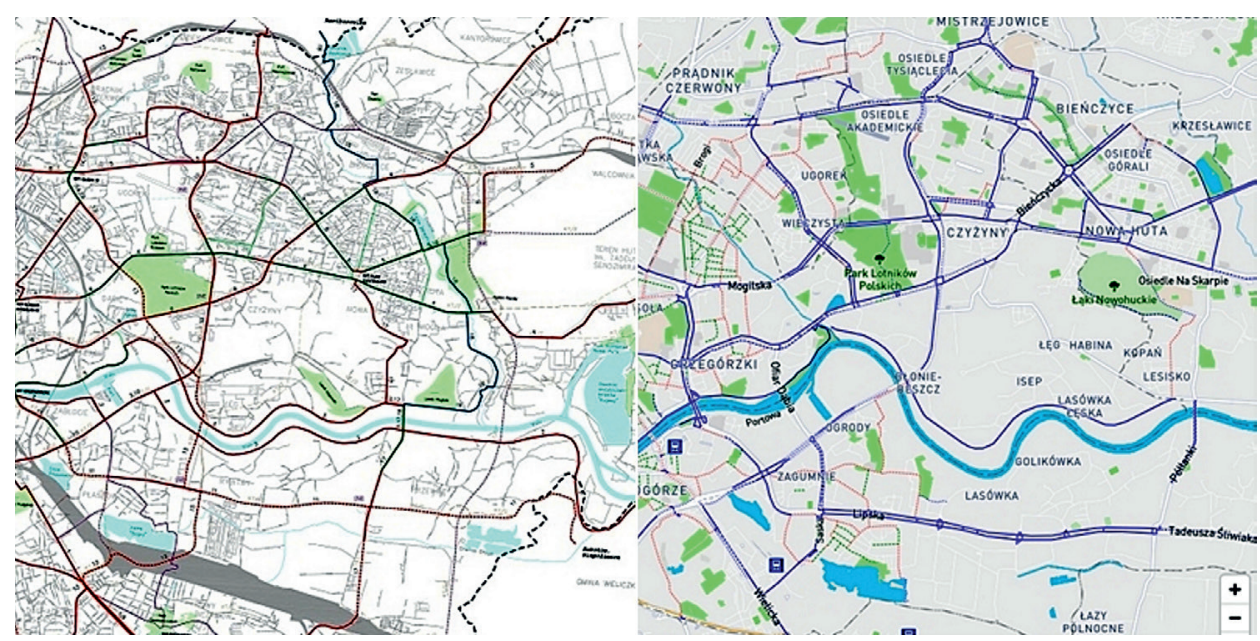

Ryc. 10. Planowane w Studium Sieci Tras Rowerowych (2010) i zrealizowane do 2019 r. odcinki infrastruktury rowerowej we wschodniej części Krakowa (opracowanie własne)

Fig. 10. Cycling road system sections planned in the Study of the Cycle Route Network (2010) and completed by 2019 in the eastern part of Cracow (own elaboration)

\section{Rozwój system roweru miejskiego w Krakowie}

Kraków jako pierwsze polskie miasto wprowadził w 2008 r. system wypożyczalni rowerów miejskich, który składał się z 12 stacji oraz ze 100 rowerów. Początkowo system został otwarty na miesiąc. Projekt miejskiej wypożyczalni był w części finansowany z unijnego projektu „Civitas II - Caravel”. W kwietniu 2009 r. system uruchomiono ponownie, a jego operatorem została firma Sanmarger Team Sp. z o.o., z której wydzielono specjalną jednostkę rowerową pod nazwą BikeOne (Bryniarska, Wilk 2018). Okres zobowiązania obejmował trzy lata. System został powiększony o cztery stacje (jedna z funduszy miejskich, trzy z funduszy sponsora - firmy Polkomtel SA) oraz 20 rowerów. W latach 2008-2009 pierwsze 20 minut wypożyczenia roweru było darmowe. W $2010 \mathrm{r}$. czas ten przedłużono do 30 minut. Szacuje się, że liczba wypożyczeń rowerów miejskich w 2009 r. wyniosła ok. 35 tys. (Hubka, Malinowski 2010). Przez trzy lata funkcjonowania rowerów miejskich w systemie zarejestrowało się ok. 6 tys. użytkowników, z czego ok. 4 tys. było aktywnych. Liczba wypożyczeń w latach 2009-2011 wynosiła 147,6 tys.

W 2012 r. przetarg na nowego operatora rowerów miejskich wygrała firma RoweRes. Firma podpisała umowę na 10 lat, jednakże w kwietniu 2013 r. została ona zerwana. Zarząd Infrastruktury Komunalnej i Transportu zaczął sam zarządzać systemem rowerów miejskich pod nazwą KMK Bike (Bryniarska, Wilk 2018). W 2014 r. operatorem technicznym KMK Bike została firma BikeU. 
System został powiększony do 305 rowerów i 34 stacji. Na każdej ze stacji było ok. 30 miejsc do dokowania rowerów. W porównaniu do 2010 r. liczba użytkowników rowerów miejskich zwiększyła się siedmiokrotnie. Rowerzyści najczęściej wypożyczali rowery w czerwcu, a najrzadziej w kwietniu. Największą popularnością cieszyły się trzy stacje: obok Teatru Bagatela, na Placu Wszystkich Świętych oraz na Placu Inwalidów.

Pod koniec grudnia 2015 r. został ogłoszony przetarg na nowego operatora roweru miejskiego, który wygrała firma Smart Bike. System wystartował 27 marca, a w jego skład weszły 34 stacje i 300 rowerów. W 2016 r. podpisano kolejną umowę, tym razem na osiem lat, z nowym operatorem - konsorcjum firm BikeU i Social Bicycles, które zmieniło nazwę na Wavelo, wyłonioną w drodze plebiscytu. System ruszył dopiero w połowie października 2016 r. i obejmował 15 stacji oraz 100 rowerów. Na początku kwietnia 2017 r. system liczył już 142 stacje oraz 840 rowerów. W lipcu 2018 r. na 163 stacjach (w tym 7 sponsorskich i 1 mobilna) dostępnych było 1500 rowerów (z tego $500 \mathrm{w}$ sezonie zimowym) (Bryniarska, Wilk 2018). W 2019 r. krakowianie mogli skorzystać z 1500 rowerów, które były rozmieszczone na 168 stacjach (ryc. 11).

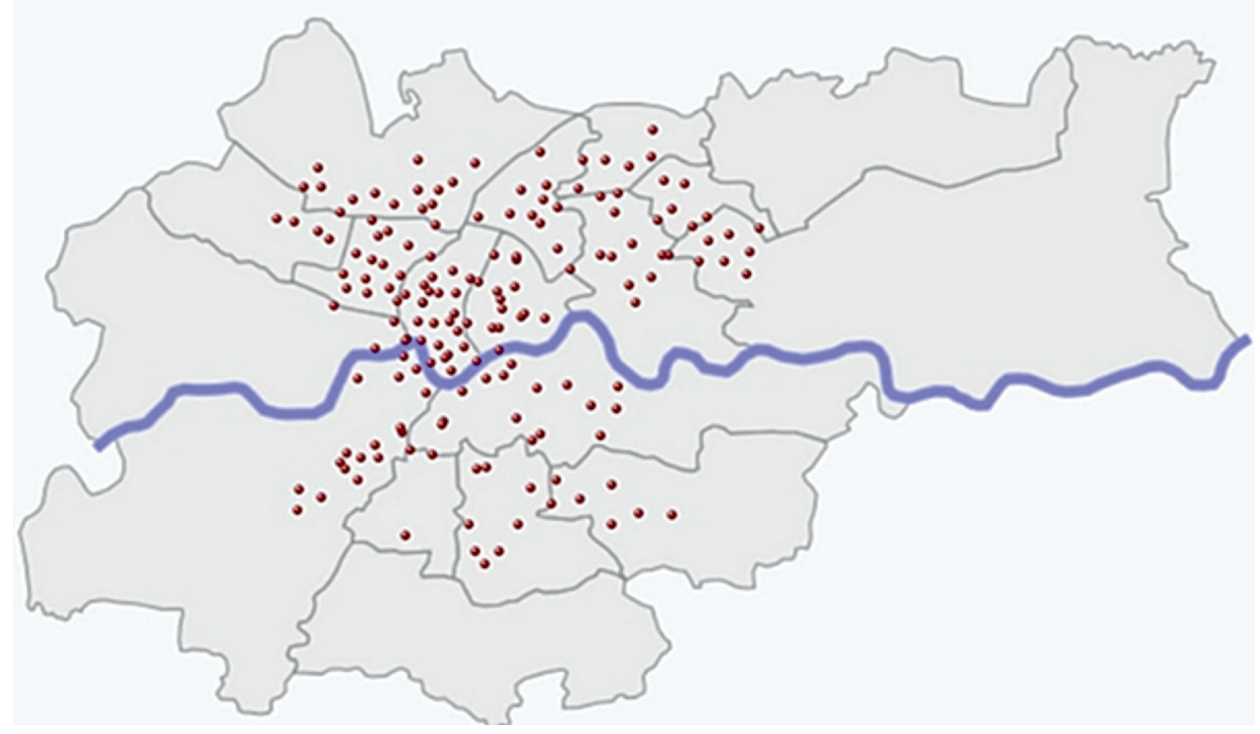

Ryc. 11. Lokalizacja stacji Wavelo w Krakowie w 2019 r. (na podstawie https://wavelo.pl)

Fig. 11. Location of the Wavelo stations in Cracow in 2019 (based on https://wavelo.pl)

Podsumowując okres działania Wavelo, należy wskazać, że przez cztery lata przybyło ponad 90 tys. użytkowników, a liczba wypożyczeń wyniosła ponad 2,5 mln (tab. 2). 
Tab. 2. Rozwój systemu roweru miejskiego w Krakowie w latach 2016-2019 (opracowanie własne na podstawie danych Wavelo)

Table 2. Development of the bicycle-sharing system in Cracow in 2016-2019 (own elaboration based on the Wavelo data)

\begin{tabular}{|c|c|c|c|c|}
\hline Rok & Liczba stacji & Liczba rowerów & Liczba użytkowników & Liczba wypożyczeń \\
\hline 2016 & 142 & 100 & 536 & 3779 \\
\hline 2017 & 157 & 300 & 35930 & 749495 \\
\hline 2018 & 165 & 840 & 70367 & 987204 \\
\hline 2019 & 168 & 1500 & 91297 & 842303 \\
\hline
\end{tabular}

Wypożyczenie roweru wiązało się z uiszczeniem opłaty. Plan abonamentowy składał się z kilku wariantów, m.in. miesięcznego (60 min/dziennie -20 zł, $90 \mathrm{~min} /$ dziennie $-25 \mathrm{zl}, 12 \mathrm{~h} /$ dziennie $-29 \mathrm{zł})$ i minutowego $(0,2 \mathrm{zł} / \mathrm{min})$. System posiadał opcje powiązania z Kartą Miejską lub OK System. Dodatkowe opłaty naliczano w momencie, gdy użytkownik zapiął rower poza stacją (3 zł) lub poza wyznaczonym obszarem działania wypożyczalni (100 zł). Użytkownicy otrzymywali bonus za przyprowadzenie roweru do stacji (Bryniarska, Wilk 2018).

Informacje związane z działaniem systemu roweru publicznego, wraz z materiałami graficznymi, edukacyjnymi oraz statystykami Wavelo i wynikami pomiaru ruchu rowerowego, dostępne są na portalu prowadzonym przez Zarząd Transportu Publicznego w Krakowie (https://mobilnykraków.pl/rowery).

\section{ROZWÓJ INFRASTRUKTURY ROWEROWEJ A DZIAŁANIE ROWERU MIEJSKIEGO W LUBLINIE}

\section{Zapisy dokumentów programowych a realizacja infrastruktury rowerowej w Lublinie}

W przypadku Lublina zapisy dotyczące transportu rowerowego pojawiły się w 2000 r. w Studium uwarunkowań i kierunków zagospodarowania przestrzennego miasta Lublina. Początkowo drogi rowerowe miały być przeznaczone na cele turystyczne i rekreacyjne. Działania związane z rozwojem infrastruktury rowerowej przybrały na sile po $2010 \mathrm{r}$. Z jednej strony znalazło to wyraz w powstaniu dokumentów strategicznych dotyczących stricte polityki rowerowej, które uchwalono w latach 2010-2015. Z drugiej strony w strukturach Urzędu Miasta utworzono najpierw stanowisko ds. polityki rowerowej, a następnie w 2014 r. powołano Oficera Rowerowego. Dokumentem określającym cele strategiczne ruchu rowerowego jest Polityka Rowerowa Miasta Lublin z 2011 r. (Uchwała nr 224/XIV/2011). Hasło przewodnie to „Lublin miastem przyjaznym rowerzystom”. Uszczegółowienie zapisów polityki rowerowej znalazło się w Koncepcji rozwoju komunikacji rowerowej w mieście Lublin (Uchwała nr 260/XV/2011), 
Tab. 3. Rozbudowa infrastruktury rowerowej w Lublinie w latach 2010-2019 (opracowanie własne) Table 3. Expansion of bicycle infrastructure in Lublin in 2010-2019 (own elaboration)

\begin{tabular}{|c|c|c|}
\hline \multicolumn{2}{|c|}{$\begin{array}{l}\text { Długość infrastruktury } \\
\qquad \mathrm{w} \text { km }\end{array}$} & Opis działań \\
\hline 2010 & 34,9 & \multirow{3}{*}{$\begin{array}{l}\text { Do } 2010 \text { r. sieć tras rowerowych liczyła ok. } 35 \text { km, z czego } \\
\text { większość stanowiła infrastruktura zlokalizowana na obszarach } \\
\text { rekreacyjnych - wzdłuż rzeki Bystrzycy i Zalewu Zemborzyckiego }\end{array}$} \\
\hline pasy rowerowe & - & \\
\hline kontraruch & - & \\
\hline 2011 & 48,5 & \multirow{3}{*}{$\begin{array}{l}\text { Powstało 13,6 km dróg rowerowych. Zostały zbudowane odcinki } \\
\text { tras rowerowych w Parku Jana Pawła II oraz wzdłuż Zalewu Ze- } \\
\text { mborzyckiego. Ponadto drogi rowerowe znalazły się w dzielni- } \\
\text { cach: Felin, Czechów Południowy oraz Czechów Północny }\end{array}$} \\
\hline pasy rowerowe & - & \\
\hline kontraruch & - & \\
\hline 2012 & 62,0 & \multirow{3}{*}{$\begin{array}{l}\text { Powstało } 7 \mathrm{~km} \text { dróg rowerowych, w tym pierwszy kontrapas } \\
\text { na wiadukcie przy ul. Grygowej we wschodniej części miasta }\end{array}$} \\
\hline pasy rowerowe & 5,7 & \\
\hline kontraruch & 0,7 & \\
\hline 2013 & 73,0 & \multirow{3}{*}{$\begin{array}{l}\text { Powstało 9,6 km dróg rowerowych oraz 1,3 km pasów ruchu dla } \\
\text { rowerów }\end{array}$} \\
\hline pasy ro & 7,0 & \\
\hline kontraruch & & \\
\hline 2014 & 109,8 & \multirow{3}{*}{$\begin{array}{l}\text { Powstało } 17,7 \mathrm{~km} \text { dróg rowerowych, } 17,5 \mathrm{~km} \text { pasów rowerowych } \\
\text { oraz } 0,8 \mathrm{~km} \text { kontraruchu w centralnych częściach miasta (ul. Ko- } \\
\text { zia, Konopnickiej, Orla, Środkowa, Wschodnia) i kolejne } 0,7 \mathrm{~km} \\
\text { na wiadukcie przy ul. Grygowej }\end{array}$} \\
\hline pasy rowerowe & 24,5 & \\
\hline kontraruch & 1,5 & \\
\hline 2015 & 126,1 & \multirow{3}{*}{$\begin{array}{l}\text { Powstało } 19,4 \mathrm{~km} \text { dróg rowerowych, 1,8 km pasów rowerowych } \\
\text { oraz pierwsza w Lublinie śluza rowerowa w północno-zachodniej } \\
\text { części miasta przy ul. Zbożowej. Zostały poprowadzone dwa pasy } \\
\text { rowerowe na Bronowicach (ul. Łęczyńska) oraz w Śródmieściu } \\
\text { (ul. Zamojska) }\end{array}$} \\
\hline pasy rowerowe & 26,3 & \\
\hline kontraruch & 1,5 & \\
\hline 2016 & 134,6 & \multirow{3}{*}{$\begin{array}{l}\text { Powstało } 7 \mathrm{~km} \text { dróg rowerowych oraz wprowadzono kontraruch } \\
\text { o łącznej długości } 1,5 \mathrm{~km} \text { na } 13 \text { ulicach }\end{array}$} \\
\hline pasy rowerowe & 26,3 & \\
\hline kontraruch & 3,0 & \\
\hline 2017 & 141,5 & \multirow{3}{*}{$\begin{array}{l}\text { Powstało } 6,7 \mathrm{~km} \text { dróg rowerowych oraz } 0,2 \mathrm{~km} \text { pasów } \\
\text { rowerowych }\end{array}$} \\
\hline pasy rowerowe & 26,5 & \\
\hline kontraruch & & \\
\hline 2018 & 152,4 & \multirow{3}{*}{$\begin{array}{l}\text { Powstało } 10,6 \mathrm{~km} \text { dróg rowerowych w dzielnicach: Szerokie, Kon- } \\
\text { stantynów oraz Sławin. Powstał kolejny pas rowerowy w dzielnicy } \\
\text { Bronowice (ul. Grabskiego) }\end{array}$} \\
\hline pasy rowerowe & 26,7 & \\
\hline kontraruch & 3,2 & \\
\hline 2019 & 170,5 & \multirow{3}{*}{$\begin{array}{l}\text { Powstało } 18,2 \mathrm{~km} \text { dróg rowerowych. W pobliżu pętli autobusowej } \\
\text { w północnej części miasta (ul. Choiny) zostało zlokalizowanych } \\
50 \text { stojaków rowerowych. Powstały } 2 \text { stacje samodzielnej naprawy } \\
\text { rowerów oraz } 30 \text { stojaków rowerowych w trakcie budowy Ronda } \\
\text { Lubelskiego Lipca }\end{array}$} \\
\hline pasy rowerowe & 26,7 & \\
\hline kontraruch & 3,2 & \\
\hline
\end{tabular}

wskazującej jednoznacznie na potrzebę współpracy miasta oraz sąsiednich gmin w zakresie rozbudowy systemu tras rowerowych i ich integracji ze środkami komunikacji publicznej, a także w Strategii realizacji systemu dróg rowerowych 
w mieście Lublin wraz z oceną oddziaływania na środowisko z 2014 r. Dokument zakładał powiększenie do $2020 \mathrm{r}$. systemu tras rowerowych do $203 \mathrm{~km}$, a także budowę 13 wiaduktów oraz kładek z dopuszczonym ruchem rowerowym. Biorąc pod uwagę stan infrastruktury rowerowej w 2014 r. w Strategii zaproponowano 52 korytarze rowerowe (ryc. 11).

Mijający rok 2020 sprzyja ocenie realizacji zapisów omawianych dokumentów. Rozbudowę infrastruktury rowerowej w Lublinie zestawiono w tab. 3.

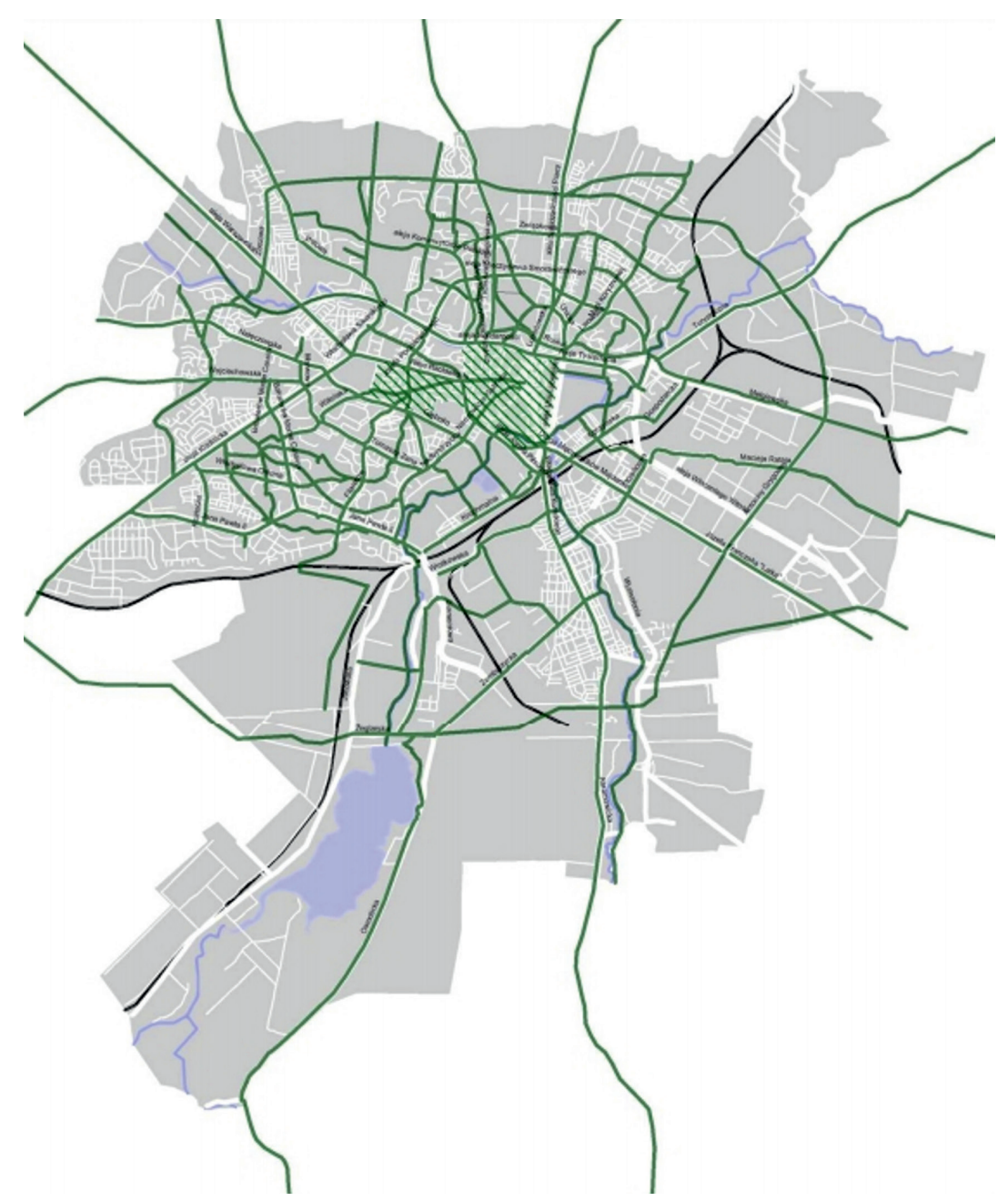

Ryc. 12. Planowane korytarze tras rowerowych w 2020 r. (na podstawie załącznika do Strategii realizacji systemu dróg rowerowych 2014)

Fig. 12. Planned bicycle route corridors in 2020 (based on Appendix to the Strategy for Implementation of the Cycling Road System 2014) 
W 2019 r. w Lublinie długość infrastruktury rowerowej wynosiła 170,5 km. W stosunku do $2010 \mathrm{r}$. przybyło łącznie $135 \mathrm{~km}$, czyli tyle samo co w ponad dwukrotnie większym Krakowie. Najwyższy przyrost odnotowano w latach 2013 i $2014(37 \mathrm{~km})$ w związku z budową pasów i dróg rowerowych w ramach realizacji projektu „Europejska Stolica Turystyki Rowerowej”.

Porównanie założeń Strategii realizacji systemu dróg rowerowych (2014) (ryc. 12) ze stanem infrastruktury rowerowej w 2019 r. (ryc. 13) pokazuje, że

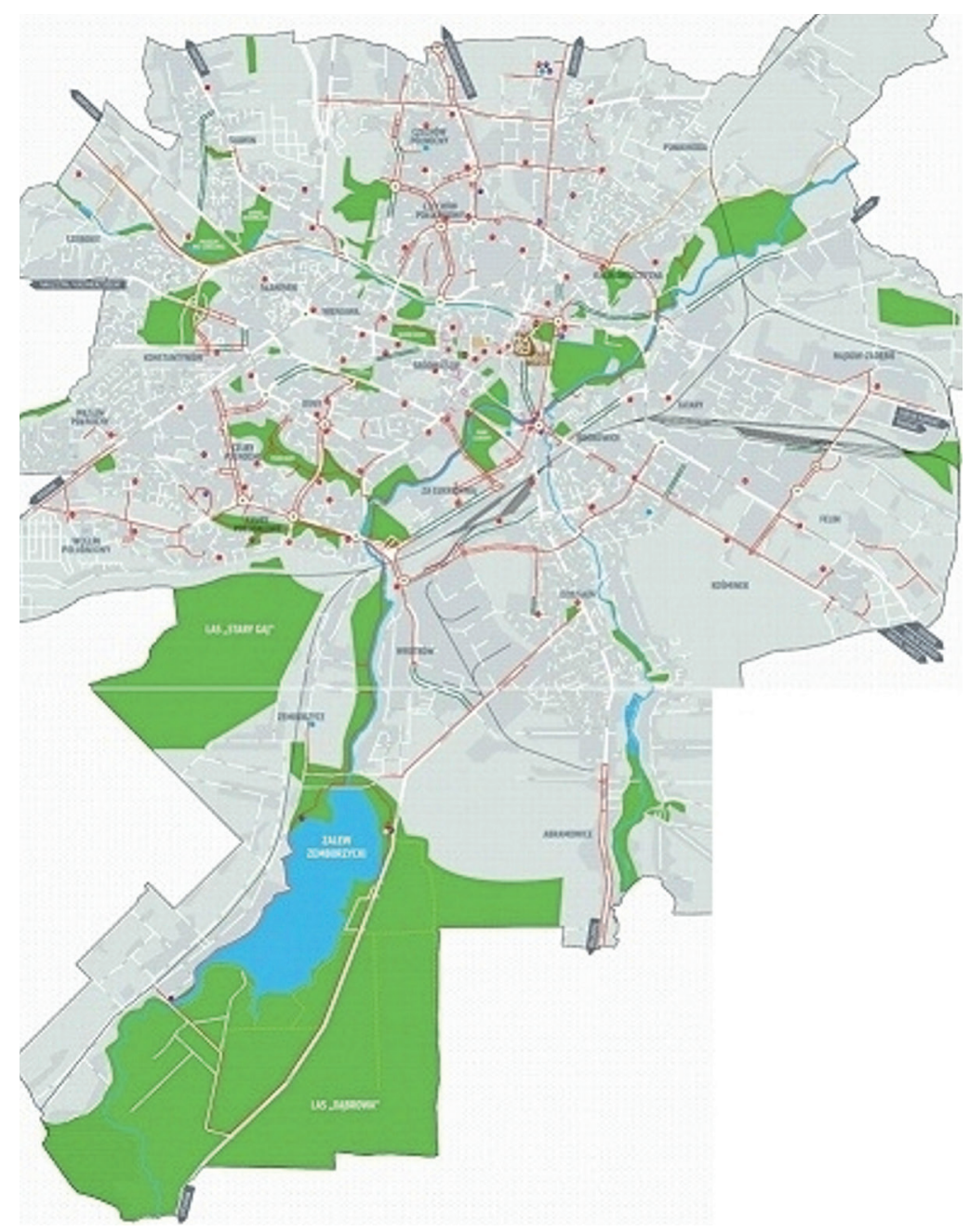

Ryc. 13. Rozmieszczenie infrastruktury rowerowej w Lublinie w 2019 r. (na podstawie https://lublin.eu/lublin/przestrzen-miejska/aktualnosci/lublin-przyjazny-rowerzystom,95,2133,1.html) Fig. 13. Location of the bicycle infrastructure in Lublin in 2019 (based on https://lublin.eu/lublin/przestrzenmiejska/aktualnosci/lublin-przyjazny-rowerzystom,95,2133,1.html) 
nie wszystkie planowane odcinki dróg zostały zrealizowane, przez co sieć infrastruktury nadal jest niespójna.

Dotyczy to inwestycji w dzielnicach Śródmieście oraz Stare Miasto (przy ulicach Rusałki i Wodopojnej, połączenia ul. Podzamcze z al. Unii Lubelskiej, dopuszczenia ruchu rowerowego na Krakowskim Przedmieściu - obecnie trwa przebudowa ulicy) (ryc. 14). W południowej części miasta dotychczas nie zrealizowano dróg rowerowych w dzielnicach Wrotków i Abramowice (na ulicach: Smoluchowskiego, Budowlanej, Romera, Nałkowskich oraz Abramowickiej) (ryc. 15). W zachodniej części miasta nadal brakuje poszczególnych odcinków dróg rowerowych, zarówno w ciągach ulic (np. al. Kraśnickiej oraz ulicach Poznańskiej, Roztocze i Orkana), jak i wewnątrz osiedli mieszkaniowych (ryc. 16). Jedynie w północnej części miasta, w dzielnicach Choiny, Czechów Północny oraz Czechów Południowy, praktycznie przy każdej głównej ulicy znajduje się infrastruktura dedykowana rowerzystom. Należy przy tym zaznaczyć, że nadal nie zrealizowano kilku korytarzy zaplanowanych w Strategii realizacji systemu dróg rowerowych (2014), m.in. przy ulicach: Walecznych, Szeligowskiego, al. Solidarności, Obywatelskiej, Chodźki i Kosmowskiej, a także wewnątrz osiedli mieszkaniowych (ryc. 17).

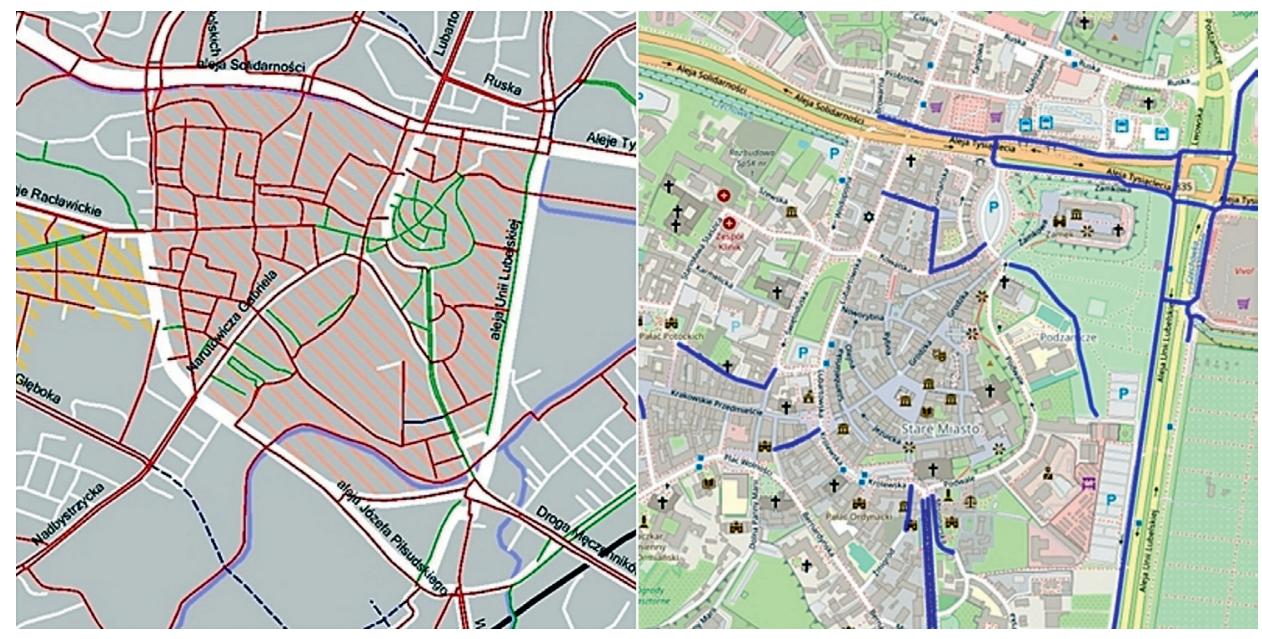

Ryc. 14. Planowane w Strategii realizacji systemu dróg rowerowych (2014) i zrealizowane do 2019 r. odcinki infrastruktury rowerowej na Starym Mieście w Lublinie (opracowanie własne)

Fig. 14. Cycling road system sections planned in the Strategy for Implementation of the Cycling Road System (2014) and completed by 2019 in the Old Town of Lublin (own elaboration) 


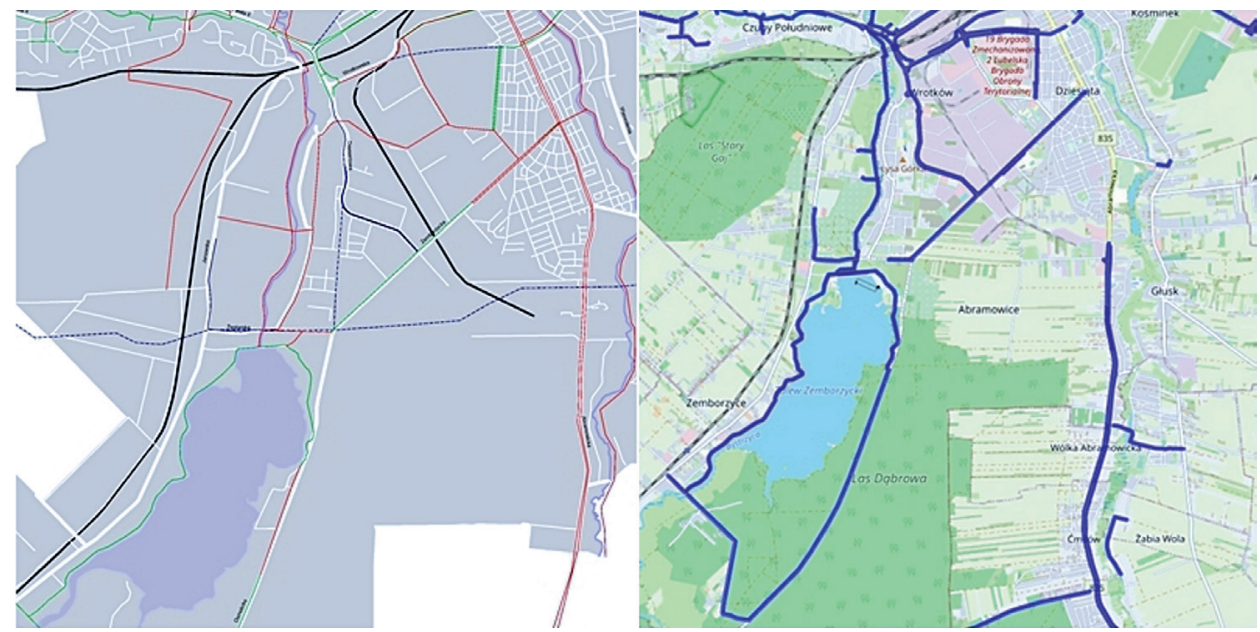

Ryc. 15. Planowane w Strategii realizacji systemu dróg rowerowych (2014) i zrealizowane do $2019 \mathrm{r}$. odcinki infrastruktury rowerowej w południowej części Lublina (opracowanie własne)

Fig. 15. Cycling road system sections planned in the Strategy for Implementation of the Cycling Road System (2014) and completed by 2019 in the southern part of Lublin (own elaboration)

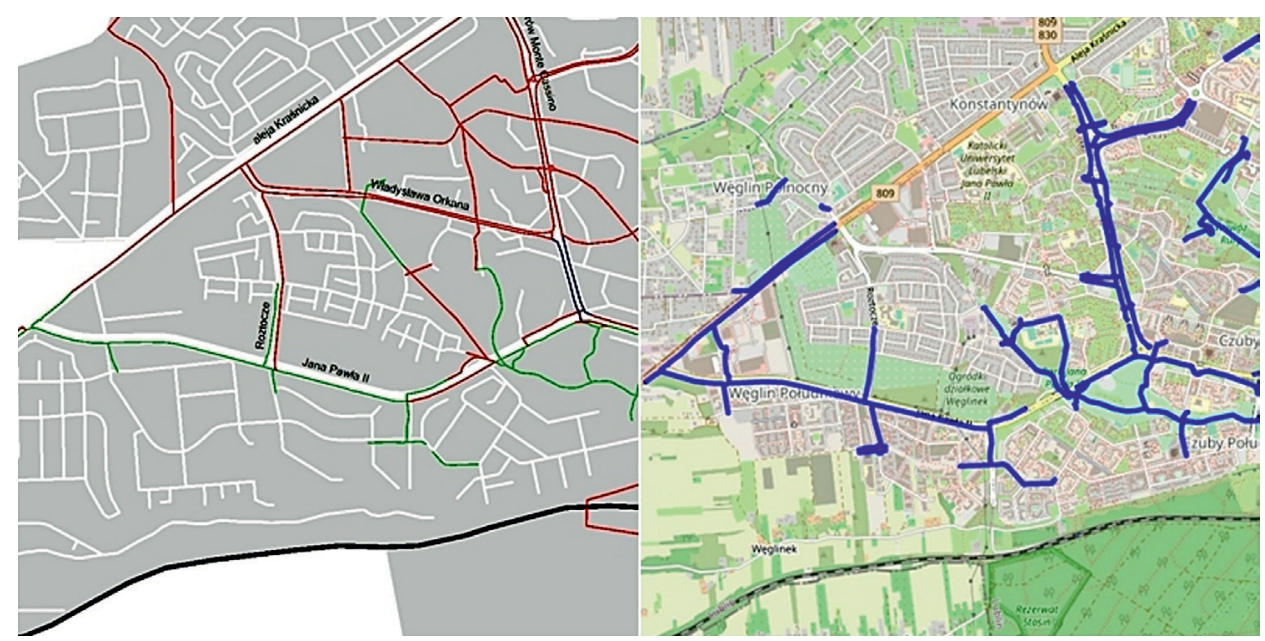

Ryc. 16. Planowane w Strategii realizacji systemu dróg rowerowych (2014) i zrealizowane do $2019 \mathrm{r}$. odcinki infrastruktury rowerowej w zachodniej części Lublina (opracowanie własne)

Fig. 16. Cycling road system sections planned in the Strategy for Implementation of the Cycling Road System (2014) and completed by 2019 in the western part of Lublin (own elaboration) 


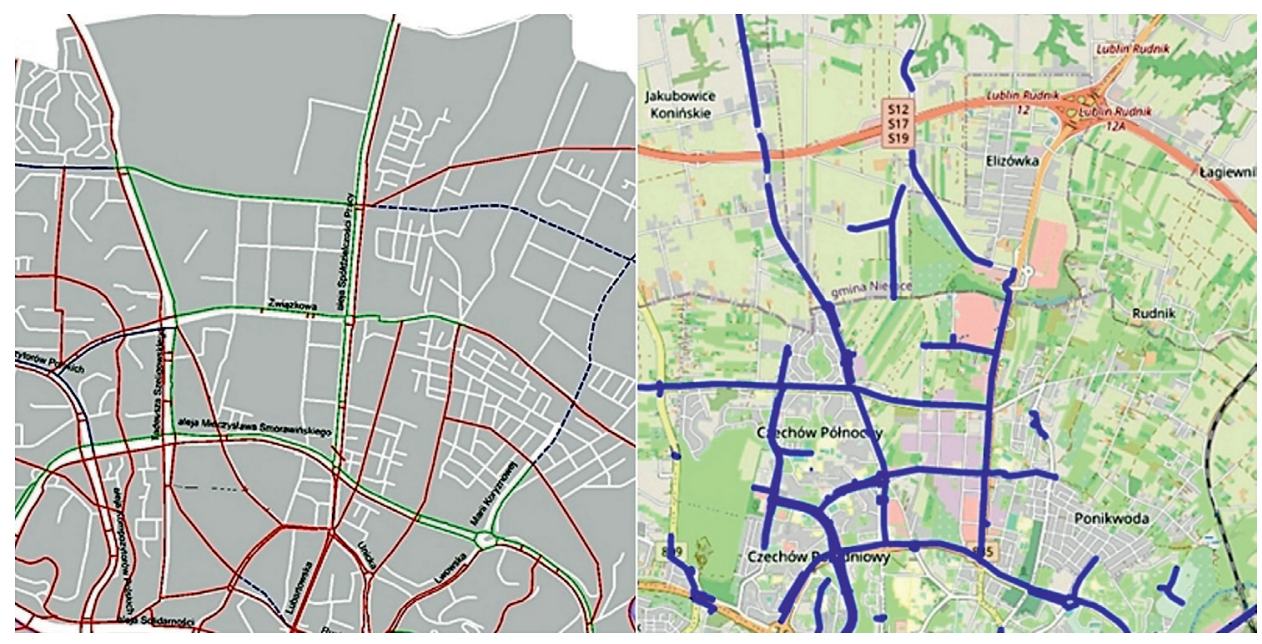

Ryc. 17. Planowane w Strategii realizacji systemu dróg rowerowych (2014) i zrealizowane do $2019 \mathrm{r}$. odcinki infrastruktury rowerowej w północnej części Lublina (opracowanie własne)

Fig. 17. Cycling road system sections planned in the Strategy for Implementation of the Cycling Road System (2014) and completed by 2019 in the northern part of Lublin (own elaboration)

\section{Rozwój systemu Lubelskiego Roweru Miejskiego}

Lubelski Rower Miejski (LRM) rozpoczął działalność w 2014 r. Operatorem jest firma Nextbike. Początkowo zostało oddanych do użytku 400 rowerów, ulokowanych na 40 stacjach. Po pierwszym sezonie w systemie zarejestrowało się 22218 użytkowników (Caban, Jóźwik, Kozłowski 2015); w kolejnych latach ich liczba równomiernie rosła. Lublin wdrażał system w ramach projektu „Europejska stolica turystyki rowerowej” finansowanego w ramach RPO WL 2007-2013, bardzo mocno podkreślając turystyczny charakter przedsięwzięcia oraz aspekty proekologiczne. Po sześciu latach działania systemu zanotowano ponad dwukrotny wzrost liczby rowerów (tab. 4). Były one rozmieszone w 98 stacjach (ryc. 18), w tym w 9 stacjach sponsorskich. W ostatnich latach dzięki współpracy z PKN ORLEN i miastem Świdnik zostały otwarte nowe stacje rowerowe, a system LRM objął również teren Świdnika (obecnie znajduje się tu 5 wypożyczalni). Trwają prace nad połączeniem obu miast systemem infrastruktury rowerowej (Kociuba, Lubaś 2018). W 2019 r. odbyło się 600 kursów międzymiastowych, co stanowi 0,1\% wszystkich wypożyczeń. W 2016 r. w ramach współpracy aktywistów rowerowych z Miejską Biblioteką Publiczną powstała Społeczna Wypożyczalnia Cargo. Do wypożyczenia roweru konieczna jest karta biblioteczna (www.cargo. lublinrowerem.pl). 
Tab. 4. Rozwój systemu roweru miejskiego w Lublinie w latach 2014-2019 (opracowanie własne na podstawie https://lubelskirower.pl)

Table 4. Development of the bicycle-sharing system in Lublin in 2014-2019 (own elaboration based on https:// lubelskirower:pl)

\begin{tabular}{|c|c|c|c|c|}
\hline Rok & Liczba stacji & Liczba rowerów & Liczba użytkowników & Liczba wypożyczeń \\
\hline 2014 & 40 & 400 & 22800 & 128644 \\
\hline 2015 & 43 & 430 & 41000 & 436965 \\
\hline 2016 & 90 & 891 & 64000 & 854881 \\
\hline 2017 & 91 & 901 & 76000 & 562000 \\
\hline 2018 & 97 & 951 & 90000 & 745000 \\
\hline 2019 & 98 & 961 & 108000 & 658700 \\
\hline
\end{tabular}

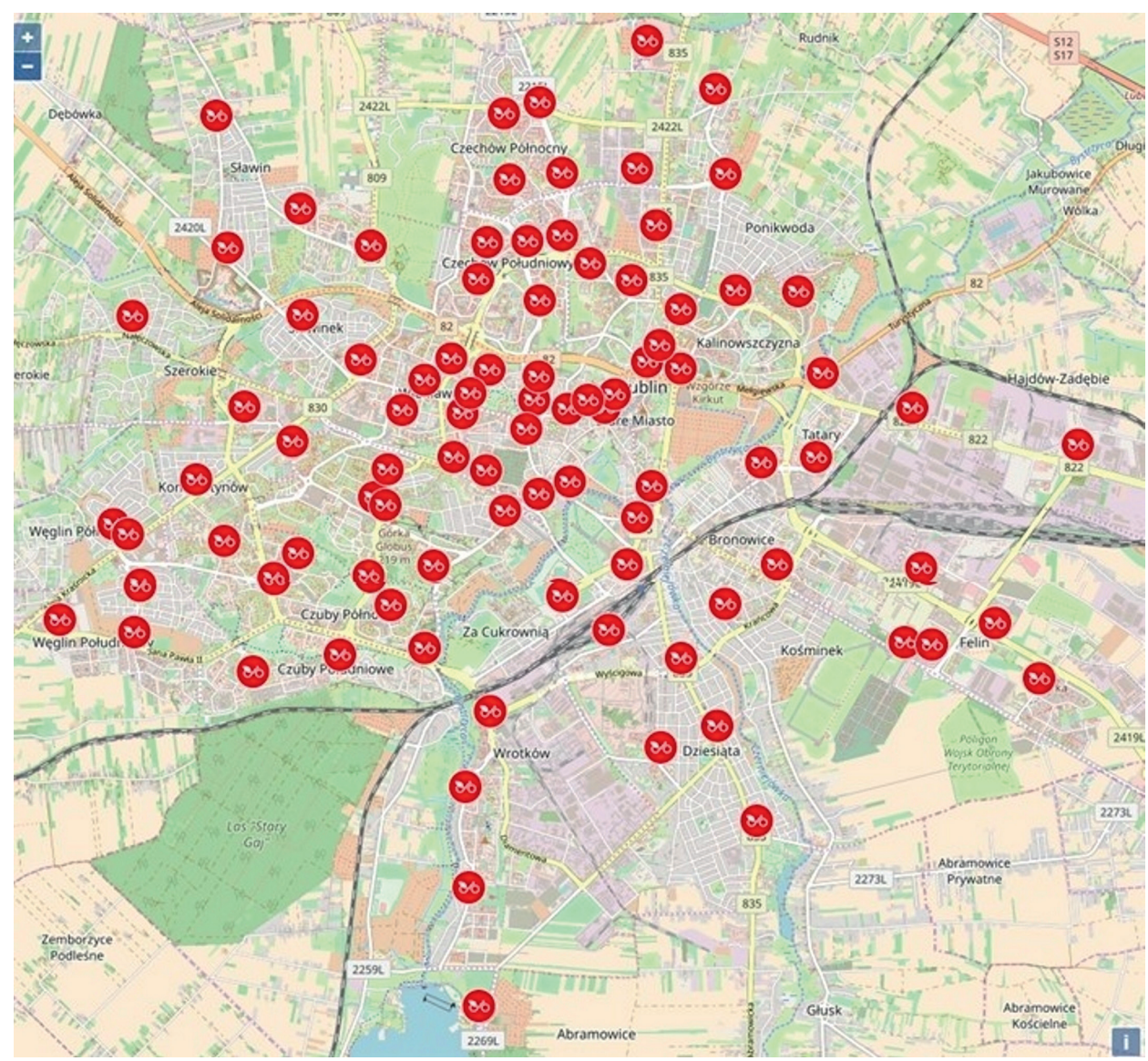

Ryc. 18. Lokalizacja stacji Lubelskiego Roweru Miejskiego w 2019 r. (na podstawie https://lubelskirower.pl/mapa-stacji)

Fig. 18. Location of the Lublin City Bike stations (based on https://lubelskirower.pl/mapa-stacji) 
Od września 2014 r. do końca listopada 2019 r. rowery zostały wypożyczone ponad 3,3 mln razy. Największa liczba wypożyczeń w trakcie działania systemu została zanotowana w 2016 r. i wynosiła 854 tys. Firma Nextbike oszacowała, że łączny czas przejazdów rowerami wyniósł ponad 100 lat. W latach 2014-2018 odnotowano, że $81 \%$ przejazdów rowerami miejskimi trwało do 20 minut, czyli odbywało się bez opłat. Około $16 \%$ stanowiły przejazdy od 30 minut do godziny (koszt 1 zł), 2\% - od 1 do 2 godzin, a 1\% - powyżej 2 godziny (tab. 5). Ponad połowa wszystkich przejazdów odbywała się w maju, czerwcu i lipcu.

Tab. 5. Czas trwania przejazdów a liczba wypożyczeń LRM w latach 2014-2019 (opracowanie własne na podstawie https://mirl.info.pl/publications/statLRM)

Table 5. Duration of trips and the number of LRM rentals in 2014-2019 (own elaboration based on https://mirl. info.pl/publications/statLRM)

\begin{tabular}{|c|c|c|c|c|c|}
\hline Rok & Do 20 min & Do 30 min & Do 60 min & Do 120 min & Pozostałe \\
\hline 2014 & 97439 & 10749 & 10829 & 3881 & 1501 \\
\hline 2015 & 496796 & 54411 & 58400 & 21268 & 8785 \\
\hline 2016 & 635100 & 59111 & 54621 & 17146 & 7155 \\
\hline 2017 & 401160 & 41505 & 36513 & 11544 & 4786 \\
\hline 2018 & 519430 & 49717 & 43383 & 13672 & 5902 \\
\hline
\end{tabular}

Najpopularniejsze stacje Lubelskiego Roweru Miejskiego znajdują się na ul. Nadbystrzyckiej (Politechnika Lubelska), ul. Zamojskiej (węzeł komunikacji miejskiej), ul. Radziszewskiego (KUL i UMCS), ul. Krakowskie Przedmieście, ul. Zana (ZUS), al. Racławickich (Rondo Krwiodawców) oraz przy centrum handlowym Lublin Plaza. Lubelscy rowerzyści najchętniej przemierzali następujące trasy: Lublin Plaza - Politechnika Lubelska, Politechnika Lubelska - Pozytywistów, Plac Zamkowy - Centrum handlowe VIVO! Lublin, Zana ZUS - Politechnika Lubelska, ul. Zamojska/Stary Most - centrum handlowe VIVO! Lublin, Rondo Krwiodawców - Krakowskie Przedmieście. W mieście zlokalizowane są też stacje dziecięce LRM (rowery z kołami 20 cali).

Podstawowe informacje dotyczące lokalizacji stacji, procedury wypożyczeń i zwrotów oraz cennika dostępne są na stronie Urzędu Miasta Lublin (https:// lubelskirower.pl). Szczegółowe analizy dotyczące wykorzystania i rozbudowy systemu LRM ukazuje interaktywna Mapa Infrastruktury Rowerowej Lublina (MIRL) (https://mirl.info.pl/publications), opracowywana przez grupę lubelskich działaczy rowerowych. Można tu znaleźć statystyki dotyczące m.in. liczby wypożyczeń oraz zwrotów rowerów w poszczególnych stacjach (z rozbiciem na cykle dobowe, tygodniowe i miesięczne), głównych kierunków z danej stacji wraz z podaniem średniego czasu i długości podróży na danym kierunku, strumieni ruchu, zasięgu stacji czy ich wykorzystania, a także zestawienia dotyczące liczby 


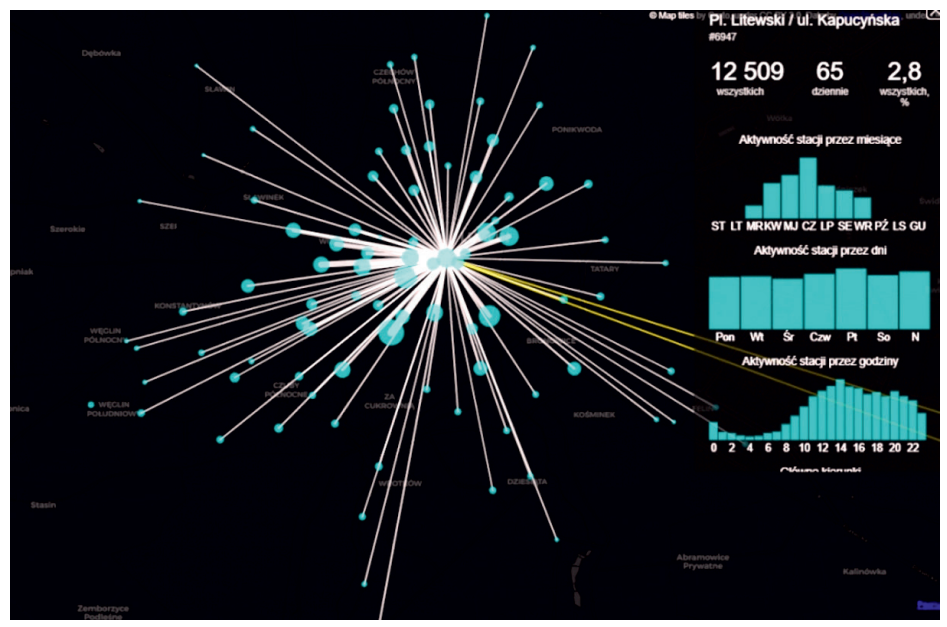

Ryc. 19. Mapa zasięgu stacji LRM pl. Litewski/ul. Kapucyńska, gdzie: niebieskie kółka oznaczają lokalizację stacji, a ich wielkość odzwierciedla liczbę wypożyczeń, linie w kolorze białym oznaczają liczbę przejazdów wykonanych z wybranej stacji, a linie żółte - tylko wyjazdy. Po nasunięciu na wybraną stację pokazuje się okienko z opisem i liczbą wszystkich wypożyczeń oraz aktywnością działania stacji w systemie dobowym, tygodniowym i miesięcznym (na podstawie https://mirl.info. $\mathrm{pl} /$ publications/statLRM/2019)

Fig. 19. Range map of the LRM Litewski square/Kapucyńska street station, where: blue circles indicate the location of the station and their size reflects the number of rentals, white lines indicate the number of rides made from the selected station, and yellow lines indicate only departures. When you click on a selected station, a window is shown with a description and number of all rentals and the activity of the station on a daily, weekly and monthly basis (based on https://mirl.info.pl/publications/statLRM/2019)

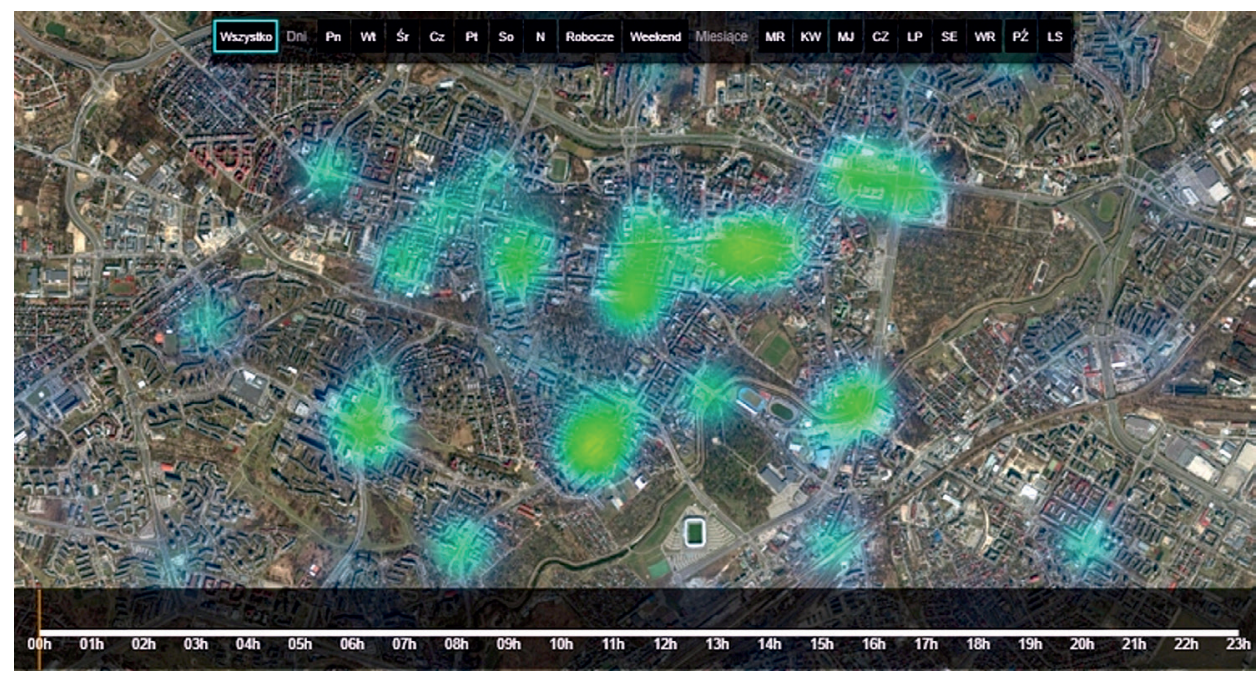

Ryc. 20. Mapa wykorzystania stacji Lubelskiego Roweru Miejskiego (wypożyczenia, zwroty) w 2019 r. (na podstawie https://mirl.info.pl/publications/statLRM/2019/heat_map)

Fig. 20. Map of the use of the Lublin City Bike stations (rentals, returns) in 2019 (based on https://mirl.info.pl/ publications/statLRM/2019/heat_map) 
użytkowników korzystających z LRM. Informacje te są zwizualizowane w formie więźby ruchu (ryc. 19), map ciepła (ryc. 20) oraz osi czasu funkcjonowania LRM i wykresów. Ponadto na portalu zamieszczane są wyniki pomiarów natężenia ruchu rowerowego w Lublinie i Świdniku, a także badań ankietowych na temat bezpieczeństwa ruchu rowerowego w mieście (m.in. w ramach Lubelskiej Ankiety Rowerowej). Dodatkowo można znaleźć dane dotyczące lokalizacji usług dla rowerzystów oraz aktualne informacje o liczbie rowerów na stacjach LRM.

\section{ROZBUDOWA INFRASTRUKTURY A ROZWÓJ SYSTEMU ROWERÓW PUBLICZNYCH}

Analizy korelacji dotyczące rozbudowy infrastruktury rowerowej w kontekście rozwoju systemu roweru miejskiego wskazują na silne związki badanych zjawisk.

W przypadku Krakowa analizy statystyczne potwierdzają większą wartość korelacji w przypadku długości kontrapasów i kontraruchu niż pasów rowerowych, co związane jest z ich długością w stosunku do długości dróg rowerowych ogółem. Ponadto zaobserwowano słabą korelację dotyczącą gęstości dróg rowerowych na $100 \mathrm{~km}^{2} \mathrm{w}$ stosunku do zmiennych odnoszących się do działania systemu roweru miejskiego, co ma związek z nierównomiernym zagęszczeniem sieci infrastruktury (głównie w centrum oraz braki na obrzeżach). Najsłabiej skorelowanymi z rozbudową infrastruktury rowerowej elementami systemu roweru miejskiego są liczba stacji i rowerów, jednak nie przekłada się to ani na liczbę użytkowników, ani na liczbę wypożyczeń (tab. 6), co można powiązać $\mathrm{z}$ charakterem inwestycji i ich przebiegiem w czasie.

Tab. 6. Korelacja rozbudowy infrastruktury z rozwojem systemu rowerów publicznych w Krakowie (opracowanie własne)

Table 6. Correlation of infrastructure expansion with the development of the public bicycle system in Cracow (own elaboration)

\begin{tabular}{|l|l|l|l|l|}
\hline \multicolumn{1}{|c|}{ Nazwa zmiennej } & \multicolumn{1}{|c|}{$\begin{array}{c}\text { Liczba } \\
\text { stacji }\end{array}$} & \multicolumn{1}{c|}{$\begin{array}{c}\text { Liczba } \\
\text { rowerów }\end{array}$} & $\begin{array}{c}\text { Liczba } \\
\text { użytkow- } \\
\text { ników }\end{array}$ & $\begin{array}{c}\text { Liczba } \\
\text { wypoży- } \\
\text { czeń }\end{array}$ \\
\hline Długość dróg rowerowych w km & $0,866831^{*}$ & $0,856321^{*}$ & $0,929971^{*}$ & $0,951918^{*}$ \\
\hline Długość pasów rowerowych w km & 0,78606 & 0,771969 & $0,897463^{*}$ & $0,987258^{*}$ \\
\hline Długość kontrapasów i kontraruchu w km & $0,842193^{*}$ & $0,848945^{*}$ & $0,923243^{*}$ & $0,949456^{*}$ \\
\hline Gęstość dróg rowerowych na $100 \mathrm{~km}^{2}$ & 0,09554 & 0,089553 & 0,017126 & $-0,014646$ \\
\hline Gęstość pasów rowerowych na $100 \mathrm{~km}^{2}$ & 0,78606 & 0,771969 & $0,897463^{*}$ & $0,987258^{*}$ \\
\hline Gęstość kontraruchu i kontrapasów na $100 \mathrm{~km}^{2}$ & $0,842429 *$ & $0,849079^{*}$ & $0,923388^{*}$ & $0,949558^{*}$ \\
\hline
\end{tabular}

* wartość istotna statystycznie na poziomie $\mathrm{p}>0,5$

* statistically significant value at $p>0.5$ 
W przypadku Lublina najniższe wartości siły związków zaobserwowano w przypadku długości i gęstości pasów rowerowych w stosunku do liczby stacji i rowerów, co świadczy o ich nieskorelowaniu w czasie w stosunku do pozostałych elementów infrastruktury. Długość i gęstość dróg rowerowych jest słabiej skorelowana z liczbą wypożyczeń (tab. 7), co wskazuje na wyższe tempo wzrostu zapotrzebowania na usługi LRM niż rozwoju infrastruktury.

Tab. 7. Korelacja rozbudowy infrastruktury z rozwojem systemu rowerów publicznych w Lublinie (opracowanie własne)

Table 7. Correlation of infrastructure expansion with the development of the public bicycle system in Lublin (own elaboration)

\begin{tabular}{|l|l|l|l|l|}
\hline \multicolumn{1}{|c|}{ Nazwa zmiennej } & \multicolumn{1}{|c|}{$\begin{array}{c}\text { Liczba } \\
\text { stacji }\end{array}$} & $\begin{array}{c}\text { Liczba } \\
\text { rowerów }\end{array}$ & $\begin{array}{c}\text { Liczba } \\
\text { użytkow- } \\
\text { ników }\end{array}$ & $\begin{array}{c}\text { Liczba } \\
\text { wypoży- } \\
\text { czeń }\end{array}$ \\
\hline Długość dróg rowerowych w km & $0,844077^{*}$ & $0,838832^{*}$ & $0,986707^{*}$ & 0,68104 \\
\hline Długość pasów rowerowych w km & 0,748191 & 0,74774 & $0,814865^{*}$ & $0,82994^{*}$ \\
\hline Długość kontrapasów i kontraruchu w km & $0,999237^{*}$ & $0,999198^{*}$ & $0,904492^{*}$ & $0,840208^{*}$ \\
\hline Gęstość dróg rowerowych na $100 \mathrm{~km}^{2}$ & $0,844828^{*}$ & $0,839585^{*}$ & $0,986935^{*}$ & 0,681134 \\
\hline Gęstość pasów rowerowych na $100 \mathrm{~km}^{2}$ & 0,743825 & 0,743455 & 0,809363 & $0,831369 *$ \\
\hline Gęstość kontrapasów i kontraruchu na $100 \mathrm{~km}^{2}$ & $0,957642 *$ & $0,953624 *$ & $0,957811^{*}$ & 0,773519 \\
\hline
\end{tabular}

* wartość istotna statystycznie na poziomie $\mathrm{p}>0,05$

* statistically significant value at $p>0.5$

\section{ROLA ORGANIZACJI I GRUP ROWEROWYCH W PROMOCJI TRANSPORTU ROWEROWEGO ORAZ ROZWOJU INFRASTRUKTURY ROWEROWEJ I SYSTEMU ROWERU MIEJSKIEGO}

Rozwój infrastruktury rowerowej i systemów roweru miejskiego nie jest efektem jedynie inwestycji realizowanych przez jednostki samorządu terytorialnego i operatorów systemu. Wpływ mają na to również działania prowadzone przez organizacje i grupy rowerowe.

\section{Działania krakowskich organizacji rowerowych}

W Krakowie działania grup rowerowych nasiliły się w latach 80 . XX w. W 1980 r. powstał Polski Klub Ekologiczny promujący działania proekologiczne, m.in. jazdę rowerem. W 1984 r. został wydany podręcznik pt. Rower w ruchu drogowym. Rozpoczęto organizację pierwszych imprez plenerowych, m.in. w ramach obchodów Dnia bez samochodu (1987) oraz Dnia Ziemi (1993). W latach 90 . Kraków był postrzegany jako miasto, w którym rodziły się ruchy 
ekologiczne i rowerowe. W 1992 r. grono działaczy rozpoczęło realizację projektu Kraków Miastem Rowerów. W 1995 r. zapoczątkowano tworzenie sieci Miasto dla Rowerów. Podjęto również realizację działań mających na celu promocję jazdy rowerem (od 2005 r. organizowanie „Masy Krytycznej”, tj. przejazdów rowerzystów przez ulice miasta w ostatni piątek miesiąca) oraz monitoring infrastruktury rowerowej (od $2001 \mathrm{r}$. audyty rowerowe). W 2009 r. władze krakowskie podpisały Kartę Brukselską, w której złożyły deklarację, że do 2020 r. ruch rowerowy ma wynosić $15 \%$ ogólnego ruchu, a liczba wypadków z rowerzystami ma się zmniejszyć o połowę.

Spowodowało to nasilenie działań związanych z promocją transportu rowerowego. Koncentrowały się one z jednej strony na rozpowszechnianiu informacji dotyczących ruchu i infrastruktury rowerowej, m.in. w 2010 r. uruchomiono serwis I bike Kraków (http://ibikekrakow.com), a od 2011 r. opracowywany jest DaRoPlan, tj. darmowy rowerowy plan miasta Krakowa. Z drugiej strony postawiono na organizację wydarzeń masowych (m.in. „Rowerem w dwóch kierunkach”, „Święto cykliczne”, „Kraków na skróty”, „Masa Krytyczna”) oraz akcji edukacyjnych (m.in. w ramach projektów „Rower - nowa kultura mobilności”; STARS - Sustainable Travel Accreditation and Recognition for Schools). Nastąpiło również sformalizowanie działalności grup, które współpracowały ze sobą przy realizacji wyżej wymienionej akcji społecznych i projektów. W 2012 r., po 18 latach działalności, zostało zarejestrowane Stowarzyszenie Kraków Miastem Rowerów (KMR) (http://kmr.org.pl), a w 2014 r. powstała Fundacja Otwarty Plan (FOP) (http://otwartyplan.org.pl).

Ważnym wydarzeniem, zainicjowanym w 2013 r. przez środowiska rowerowe, była akcja pn. „Krakowski Dialog Cykliczny”, której efektem był „Kontrakt 100 rozwiązań". Wypracowane w jego ramach wspólnie z mieszkańcami propozycje są systematycznie wdrażane przez władze Krakowa. W latach 2014-2017 miasto sfinansowało zamontowanie ponad 4 tys. stojaków na rowery w lokalizacjach wskazanych przez mieszkańców, a także wprowadziło kontraruch na ulicach w Strefie Płatnego Parkowania w centrum miasta.

W ostatnich latach działalność środowisk rowerowych koncentruje się m.in. na aktywnym włączaniu się w planowanie i społeczną kontrolę funkcjonowania infrastruktury rowerowej poprzez wystosowywanie wniosków, opiniowanie projektów nowej oraz monitoring jakości już istniejącej infrastruktury rowerowej (KMR, m.in. w ramach audytów rowerowych prowadzonych przez miasto). Ponadto aktywiści nadal prowadzą działania edukacyjne („Cyklolekcje”, „Cykloakademia”, „Rowerowy Maj”, nastąpiła też reaktywacja projektu „STARS - rowerem do szkoły") oraz włączają się w organizację wydarzeń promujących ruch rowerowy w ramach Europejskiego Tygodnia Zrównoważonego Transportu. 
W większości działania i projekty realizowane są przy wsparciu finansowym Urzędu Miasta Kraków oraz Wojewódzkiego Funduszu Ochrony Środowiska i Gospodarki Wodnej w Krakowie. W 2015 r. powstał miejski portal rowerowy, w którym wykorzystywane są opracowania przygotowane przez FOP, m.in. DaRoPlan (http://mobilnykrakow.pl/mapy/mapa-rowerowa) oraz materiały edukacyjne (http://mobilnykrakow.pl/rowery/\#edukacja).

\section{Działalność lubelskiego ekosystemu rowerowego}

Tradycje lubelskich organizacji rowerowych sięgają końca XIX w. W 1893 r. w Lublinie rozpoczął działalność pierwszy klub rowerowy o nazwie Lubelskie Towarzystwo Cyklistów. Z inicjatywy działaczy w mieście wybudowano kilka torów rowerowych, na których uczono jazdy na rowerze (Brzuszkiewicz 2014). Reaktywacja działań klubu rowerowego nastąpiła w latach 60. XX w., kiedy to przy Oddziale Miejskim PTTK rozpoczął swoją działalność Lubelski Klub Turystyki Kolarskiej „Welocyped”. W latach 1965-1966 jego członkowie zakupili z datków 10 rowerów i zorganizowali pierwszą w mieście wypożyczalnię (w tym samym czasie w Amsterdamie pojawiły się pierwsze Witte Fietsen [Białe Rowery]) oraz serwis do naprawy rowerów. Uczestnicy klubu wielokrotnie brali udział w licznych konkursach, wydarzeniach oraz rajdach, a także organizowali szkolenia. Działalność klubu trwała nieprzerwanie do 2008 r. (http://welocypedlubelski.pl/historia).

W 2007 r. zawiązało się Porozumienie Rowerowe, będące częścią stowarzyszenia Towarzystwo dla Natury i Człowieka (https://porozumienierowerowe.pl), którego członkowie bardzo aktywnie włączyli się w działania wspierające rozwój ruchu rowerowego. W 2009 r. grupa dołączyła do ogólnopolskiej sieci Miasta dla Rowerów. W 2015 r. sformalizowało swe działanie Stowarzyszenie Świdnik Miasto dla Rowerów, które stanowi kontynuację grupy nieformalnej Świdnicka Masa Krytyczna (http://swidnikmiastodlarowerow.pl). Organizacje te ściśle współpracują ze sobą, a z ich szeregów wywodzą się lubelscy Oficerowie Rowerowi.

Z punktu widzenia kształtowania polityki rowerowej miasta do najważniejszych inicjatyw realizowanych przez członków organizacji rowerowych należy zaliczyć opracowanie i bieżącą aktualizację interaktywnej Mapy Infrastruktury Rowerowej Lublina (https://mirl.info.pl/mapa). Stanowi ona kompendium wiedzy na temat infrastruktury rowerowej i ruchu rowerowego w mieście. Na mapie można znaleźć informacje dotyczące przebiegu tras rowerowych, projektów zmian w organizacji ruchu na przebudowywanych i remontowanych odcinkach dróg, a także sprawdzić, z jakiej nawierzchni wykonana jest dana trasa czy kiedy powstała. Ponadto na mapie znajdują się statystyki i opracowania związane z działaniem LRM oraz wyniki badań dotyczących ruchu rowerowego, które aktywiści prowadzą we 
współpracy z naukowcami i studentami lubelskich uczelni ${ }^{3}$. Zamieszczane są tu też różnorodne materiały edukacyjne. Bazy danych MIRL są udostępniane na stronach organizacji, a mapa $\mathrm{w}$ wersji papierowej jest wydawana przy współpracy z firmą GIS Support Sp. z o.o. Z materiałów tych korzystają zarówno miejscy urzędnicy, operator LRM, jak i użytkownicy rowerów. Portal stanowi doskonałe uzupełnienie „miejskiej” strony internetowej poświęconej LRM (https://lubelskirower.pl).

Działacze aktywnie włączają się w planowanie i rozbudowę infrastruktury rowerowej poprzez udział m.in. w konsultacjach społecznych dotyczących nowych inwestycji drogowych oraz opracowania dokumentów strategicznych i programowych. Przygotowują też propozycje niskokosztowych usprawnień infrastruktury rowerowej, zmian w systemie organizacji ruchu oraz działania LRM, które są wykorzystywane przez urzędników miejskich oraz Nextbike. Aktywiści składają również projekty „rowerowe” do budżetu obywatelskiego, co skutkuje rozbudową infrastruktury (nowe wypożyczalnie, stojaki, rowery cargo), a także opracowują materiały informacyjno-edukacyjne (m.in. Wiącek, Gorczyca 2013; Cal 2015; na podstawie danych MIRL w ramach V edycji budżetu obywatelskiego została opracowana i wydana mapa rowerowa Lublina oraz poradnik Lublin Przyjazny Rowerzystom [2019]). W ramach współpracy Porozumienia Rowerowego z Miejską Biblioteką Publiczną rozpoczęła działalność Społeczna Wypożyczalnia Cargo.

Organizacje rowerowe prowadzą też różnorodne akcje i działania edukacyjno-promocyjne skierowane do mieszkańców Lublina. Zaliczyć do nich należy przede wszystkim organizację praktycznej edukacji rowerowej (m.in. w ramach akcji: „Lublin Rowerem”, „Kampania na rzecz zrównoważonych zachowań transportowych”, „Rodzinne warsztaty bezpiecznej jazdy rowerem”), a także prowadzenie - we współpracy z Oficerem Rowerowym - akcji informacyjno-edukacyjnych oraz konkursów w lubelskich przedszkolach (projekt „Rowerowe przedszkole - edukacja rowerowa od najmłodszych lat") i szkołach (m.in. kampanie: „Lublin rowerem”, „Rowerowy Maj” i „Rowerowa Wiosna”). W ramach działań popularyzatorskich organizowane są cykliczne akcje promujące rower jako ekologiczny środek transportu, np. przejazdy „Masy Krytycznej” (m.in. tematyczne, związane z lubelską tradycją i kulturą, jak np. „Lublin 700”, „Śladami 1918 roku w Lublinie”, „Sztukmistrze w Lublinie!”, „Śladami Komisarza Maciejewskiego" z pisarzem Marcinem Wrońskim), „Spotkania rowerowe”

3 Można tu zaliczyć m.in. prowadzenie badań natężenia ruchu rowerowego w Lublinie i Świdniku. W 2018 r. Stowarzyszenie Świdnik Miasto dla Rowerów zdobyło za tę inicjatywę nagrodę im. Jerzego Regulskiego w kategorii Upowszechnianie. W tym samym roku we współpracy z UMCS wydano Atlas ruchu rowerowego w Świdniku (Kociuba, Lubaś 2018). 
organizowane w dzielnicach Lublina, „Pikniki z cyklistami”, „Przejażdżki rowerowe" (Wiosenne, Letnie i Jesienne). Ponadto organizują wydarzenia w ramach Europejskiego Tygodnia Zrównoważonego Transportu oraz Bike to Work (https:// pl-pl.facebook.com/pg/lublinrowerem/events). Spektrum akcji i kampanii z roku na rok się powiększa. Działania te przynoszą wymierne efekty - coraz więcej dzieci dociera do szkoły na rowerach, a od 2017 r. wszystkie szkoły posiadają modułowe parkingi dla rowerów. Zwiększa się też liczba osób, która do przemieszczania się po mieście wykorzystują rowery.

W swoje działania organizacje rowerowe z sukcesem włączają urzędników, mieszkańców, organizacje pozarządowe, instytucje publiczne, podmioty prywatne oraz naukowców i studentów lubelskich uczelni. Z biegiem lat spowodowało to wykształcenie się swoistego lubelskiego ekosystemu rowerowego, który aktywnie wspiera wszelkie akcje i działania oraz włącza się w rozbudowę infrastruktury rowerowej, poprawę efektywności działania systemu LRM, badania ruchu rowerowego, a także edukację i promocję roweru jako ekologicznego środka transportu.

\section{ZAKOŃCZENIE}

Celem artykułu była identyfikacja dynamiki rozbudowy miejskiej infrastruktury rowerowej w kontekście rozwoju systemów roweru miejskiego. Przeprowadzone analizy pozwalają na odniesienie się do postawionych we wstępie pytań badawczych. W kwestii porównania zapisów dokumentów programowych dotyczących rozwoju infrastruktury rowerowej do stanu aktualnego stwierdzono duże rozbieżności. Dotyczą one zarówno długości infrastruktury liniowej (w Krakowie zaplanowaną na 2015 r. wartość 223 km osiągnięto dopiero w 2019 r.; w Lublinie w 2020 r. miało funkcjonować $203 \mathrm{~km}$, tymczasem do 2019 r. zrealizowano 170 km), jak i jej spójności. Przyczyn tego stanu rzeczy należy upatrywać głównie w sposobie realizacji inwestycji rowerowych, które towarzyszą zazwyczaj ,przy okazji" rozbudowie i przebudowie dróg i chodników. Duże rozproszenie tych inwestycji w granicach miast powoduje, że sieć nadal jest niespójna. Pomimo znaczących różnic w powierzchni obu miast rozbudowa infrastruktury rowerowej w latach 2010-2019 odbywała się na tym samym poziomie (przybyło po ok. $135 \mathrm{~km}$ dróg rowerowych), przy czym w Lublinie odnotowano większą dynamikę rozbudowy „twardej” infrastruktury rowerowej (drogi rowerowe, ciągi pieszo-rowerowe), natomiast w Krakowie wprowadzono więcej rozwiązań związanych ze zmianą organizacji ruchu (m.in. kontraruch, kontrapasy w Strefie Płatnego Parkowania).

W rozwoju systemów rowerów publicznych w Krakowie i Lublinie zanotowano znaczne różnice po względem czasu działania (w Krakowie od 2008 r. 
z przerwami w sezonie 2013 i 2015, a w Lublinie nieprzerwanie od 2014 r.), zarządzania systemem (w Krakowie działało sześciu operatorów, a w Lublinie jeden) oraz poboru opłat (w Krakowie od 2015 r. przejazdy są płatne w ramach abonamentu, w Lublinie zaś pierwsze 20 min jazdy jest za darmo). Znalazło to odzwierciedlenie w niewspółmiernej do liczby mieszkańców (Kraków - 779 tys., Lublin - 340 tys.) liczbie użytkowników systemów (odpowiednio 91,3 tys. i 108 tys.). Na mniejsze tempo wykorzystania roweru miejskiego w Krakowie niewątpliwie wpływ miały przerwy w działaniu systemu oraz likwidacja darmowych przejazdów, które do 2015 r. generowały ponad 85\% wszystkich wypożyczeń (Łastowska, Bryniarska 2015). Ze względu na przestoje część osób mogła zdecydować się na zakup własnych rowerów, co - biorąc pod uwagę koszty abonamentu i długość dystansu do pokonania, powiązaną z wielkością miasta - jest w dłuższej perspektywie bardziej opłacalne niż regularne korzystanie z wypożyczalni. Mogło to wpłynąć pośrednio na zmianę zachowań i profil użytkowników systemu. Tezę tę potwierdzają wyniki badań przeprowadzonych w 2015 r., które wykazały, że z roweru miejskiego najczęściej korzystali studenci lub osoby rozpoczynające pracę i nieposiadające swojego samochodu (Lastowska, Bryniarska 2015). Ponowne badania z 2018 r. (po wprowadzeniu abonamentu) wykazały, że rower miejski był wypożyczany najczęściej w celach rekreacji lub dojazdów do/z pracy, rzadziej zaś po to, by dojechać do szkoły lub na uczelnię (Bryniarska, Wilk 2018).

Powyższe problemy nie występowały w Lublinie, gdzie od początku systemem zarządzał jeden operator. W latach 2014-2019 przy stosunkowo niewielkiej rozbudowie systemu (ponad dwukrotny wzrost stacji i rowerów) zanotowano pięciokrotny wzrost zarówno liczby użytkowników, jak i wypożyczeń. Niewątpliwie wpływa na to aspekt finansowy (brak opłat przez pierwsze $20 \mathrm{~min}$ ), ale też przemyślana rozbudowa systemu, bazująca od początku na analizach wykonywanych w ramach MIRL, oraz liczne akcje edukacyjno-promocyjne, które przełożyły się na wzrost zainteresowania rowerem miejskim. Właściwe rozmieszczenie stacji daje możliwość bezpłatnego przejazdu na zaplanowanej trasie. Te zalety LRM potwierdzają również wyniki konsultacji społecznych przeprowadzonych wiosną 2020 r., w trakcie których blisko połowa respondentów jako atut wskazała bezpłatny okres wypożyczenia oraz potwierdziła dobrą jakość działania systemu (67\%), w tym lokalizacji stacji (77\%). W przypadku Lublina z systemu LRM korzysta się zazwyczaj na krótkich odcinkach (ponad $80 \%$ stanowią wypożyczenia darmowe), w celu dotarcia zarówno do miejsc związanych z edukacją, pracą czy usługami (46\%), jak i do znajomych czy sklepu (39\%), rzadziej zaś do jazdy rekreacyjnej na dłuższych odcinkach (15\%) (Lubelska Grupa Badawcza 2020). 
Odnosząc się do zagadnień dotyczących wpływu rozbudowy infrastruktury rowerowej na rozwój systemów roweru miejskiego, należy stwierdzić, że wyniki analizy korelacji wykazały, iż powolna rozbudowa infrastruktury rowerowej oraz brak spójności sieci tras rowerowych nie miały negatywnego wpływu na rozwój systemów roweru publicznego. Można więc przyjąć, że stacje roweru publicznego stanowią cenne uzupełnienie miejskiej infrastruktury rowerowej. Należy przy tym podkreślić, że rozbudowa sieci wypożyczalni LRM ma silne wsparcie analityczne (statystyki w ramach MIRL), co powoduje, że ich lokalizacja często wyprzedza rozwój infrastruktury i jest bardzo dobrze dostosowana do potrzeb rowerzystów. Zagęszczenie stacji spowodowało m.in. zmniejszenie czasu przejazdu między nimi do 5 min. Rozwój infrastruktury rowerowej nie ma istotnego wpływu na pokrycie zasięgiem LRM, który w 2018 r. obejmował 56\% miasta; oddziałuje on jedynie na komfort jazdy oraz na tworzenie ścieżek rowerowych w miejscach niedostępnych dla samochodów (Gawroński i in. 2019). Z kolei w Krakowie lokalizacja nowych stacji nawiązuje do już istniejącej infrastruktury, co może mieć wpływ na mniejszą efektywność działania systemu (ponad pięciokrotny wzrost liczby stacji w 2018 r. spowodował tylko dwukrotny wzrost liczby użytkowników). Należy także zauważyć, że najczęściej użytkowane stacje powstają głównie przy węzłach przesiadkowych i ważnych obiektach na terenie miasta: edukacyjnych, administracyjnych, handlowych, nie zawsze w powiązaniu $\mathrm{z}$ infrastrukturą rowerową.

W kontekście wpływu działań organizacji rowerowych na rozwój infrastruktury rowerowej i systemu roweru miejskiego należy podkreślić, że zaobserwowano duże różnice w obu miastach w zakresie dynamiki prowadzanych działań, ich spektrum oraz zasad finansowania. W przypadku Krakowa największą aktywność organizacji i nieformalnych grup rowerowych zaobserwowano do połowy lat 2010., kiedy to przeprowadzono liczne akcje i kampanie edukacyjno-promocyjne oraz wypracowano „Kontrakt 100 rozwiązań” realizowany sukcesywnie przez miasto, co przyczyniło się zarówno do popularyzacji jazdy rowerem, jak i do wprowadzenia zmian w organizacji ruchu oraz powstania nowej infrastruktury rowerowej. Po sformalizowaniu struktur organizacji zaobserwowano stopniowe ograniczanie liczby inicjatyw i prowadzonych akcji, których tematyka, szczególnie w ostatnich latach, uzależniona jest w dużej mierze od finansowania zewnętrznego. Obecnie większość działań (audyty, pomiary, analizy, edukacja, opracowanie standardów rowerowych) koordynuje miasto, a ich wyniki upubliczniane są na portalu mobilnykrakow.pl. Organizacje rowerowe włączają się w jego działanie poprzez dostarczanie i aktualizację danych (DaRoPlan i materiały edukacyjne - FOP), a także biorą udział w audytach organizowanych przez miasto oraz w konsultacjach planów rozbudowy i monitoringu jakości powstającej 
infrastruktury rowerowej (KMR). Z kolei w przypadku Lublina większość działań nadal stanowią inicjatywy oddolne, oparte na kooperacji w ramach lubelskiego ekosystemu rowerowego, w mniejszym stopniu bazujące wyłącznie na finansowaniu ze środków zewnętrznych. W ciągu kilku ostatnich lat wypracowano wiele dobrych praktyk, a spektrum działań z roku na rok się powiększa. Środowiska rowerowe prowadzą szereg działań i akcji edukacyjno-promocyjnych, bardzo aktywnie włączają się w planowanie i rozbudowę infrastruktury rowerowej oraz prowadzą wieloaspektowe analizy dotyczące przebiegu dróg rowerowych, ich wykorzystania przez rowerzystów i użytkowania systemu LRM. Są one udostępniane na portalu mirl.info.pl i wykorzystywane przez miasto, operatora systemu oraz mieszkańców. Dzięki ich wysiłkom zarówno infrastruktura rowerowa, jak i system LRM odpowiadają na potrzeby użytkowników i są przez nich w coraz większym stopniu wykorzystywane.

Na koniec należy podkreślić, że włączenie środowisk rowerowych w propagowanie ruchu rowerowego i projektowanie infrastruktury rowerowej oraz uwzględnienie działań i inicjatyw oddolnych w polityce transportowej miast realnie przekłada się na jakość realizacji infrastruktury rowerowej, poprawę działania systemu roweru publicznego, wzrost natężenia ruchu rowerowego, a także stanowi doskonałe uzupełnienie działań podejmowanych przez władze miast i operatorów systemów rowerów miejskich.

\section{BIBLIOGRAFIA}

\section{Literatura}

Bartniczak B. 2013. Zrównoważony transport na poziomie regionalnym jako przedmiot pomiaru wskaźnikowego. Studia Ekonomiczne 143, 11-20.

Beim M., Brudka C., Modrzewski B., Hyła M., Puk A., Rakower R., Rychlewski J. 2015. Standardy techniczne systemu rowerowego. Poznań: Stowarzyszenie „Sekcja Rowerzystów Miejskich”.

Bencekri M., Kua D., Kimb J., Leec S., Leed S. 2020. Review of European Low Emission Zone Policy. Chemical Engineering Transactions 78, 241-246.

Bryniarska Z., Wilk N. 2018. Ocena systemu wypożyczalni rowerów miejskich Wavelo w Krakowie. Transport Miejski i Regionalny 10, 22-27.

Brzuszkiewicz T. 2014. Lubelskich cyklistów początki. Pobrane z: https://ryneklubelski.pl/2014/01/ lubelskich-cyklistow-poczatki

Buciak R., Krajewska K., Pawłowska M. 2017. Warszawski Pomiar Ruchu Rowerowego 2017. Warszawa: Zielone Mazowsze.

Caban J., Jóźwik K., Kozłowski M. 2015. Transport rowerowy w systemie komunikacyjnym Lublina. Logistyka 3, 635-642.

Cal P. 2015. Poradnik aktywnego rowerzysty. Lublin: Towarzystwo dla Natury i Człowieka.

Ciesielski P. 2014. Realizacja Polityk Rowerowych na przykładzie Kopenhagi i Krakowa. Zarzadzanie Publiczne 1, 125-136. 
Dąbrowska-Loranc M., Cielecki A., Jasiński A., Skoczyński P., Zalewski A., ..., Fiszer-Sozańska J. 2019. Podręcznik. Wytyczne organizacji bezpiecznego ruchu rowerowego. Warszawa: Ministerstwo Infrastruktury - Sekretariat Krajowej Rady Bezpieczeństwa Ruchu Drogowego.

DeMaio P. 2009. Bike-sharing: History, Impacts, Models of Provision, and Future. Journal of Public Transportation 12(4), 41-56. https://doi.org/10.5038/2375-0901.12.4.3

Dębowska-Mróz M., Kacprzak M., Zięba P. 2016. Infrastruktura rowerowa jako element systemu transportowego Radomia. Autobusy - Technika, Eksploatacja, Systemy Transportowe 17(12), $573-580$.

Dębowska-Mróz M., Lis P., Szymanek A., Zawisza T. 2017. Rower miejski jako element systemu transportowego w miastach. Autobusy - Technika, Eksploatacja, Systemy Transportowe 18(6), 1173-1182.

Gadziński J. 2011. Rozwój transportu drogowego jako zagrożenie dla środowiska przyrodniczego - przykład aglomeracji poznańskiej. JEcolHealth 15(4), 165-175.

Gawroński K., Król K., Gawrońska G., Kubicki B. 2019. Analysis of the development of Lublin city bike stations versus the economic and spatial conditions in that city. Geomatics, Landmanagement and Landscape 4, 183-199. https://doi.org/10.15576/GLL/2019.4.183

Górnośląski Związek Metropolitalny. 2016. Standardy i wytyczne kształtowania infrastruktury rowerowej. Katowice.

Hitchcock G., Vedrenne M. 2014. Cycling and Urban Air Quality: A Study of European Experiences. Bruksela: The European Cyclists' Federation.

Hubka Ł., Malinowski R. 2010. System bezobsługowej wypożyczalni rowerów miejskich w Krakowie. Transport Miejski i Regionalny 7-8, 36-41.

Kauf S., Szołtysek J., Wieczorek I. 2018. Transport zbiorowy - w zaspokajaniu mobilności mieszkańców miast - doświadczenia JST. Łódź: Narodowy Instytut Samorządu Terytorialnego.

Klimkiewicz K. 2013. Wykorzystanie systemu Veturilo w transporcie miejskim w Warszawie. Zeszyty Naukowe Politechniki Poznańskiej. Organizacja i Zarządzanie 60, 33-42.

Kłos-Adamkiewicz Z. 2014. Koszty i korzyści funkcjonowania miejskich wypożyczalni rowerów. Zeszyty Naukowe Uniwersytetu Szczecińskiego. Problemy Transportu i Logistyki 26, 55-66.

Kociuba D. 2018. Implementation of Integrated Territorial Investments in Poland - Rationale, Results, and Recommendations. Quaestiones Geographicae 37(4), 69-86. https://doi. org/10.2478/quageo-2018-0038

Kociuba D., Rabczewska K. 2019. Rola budżetów partycypacyjnych w zagospodarowaniu przestrzeni publicznych polskich miast - studium przypadku Lublina. Studia Regionalne i Lokalne 2(76), 82-109. DOI: 10.7366/1509499527605

Kociuba D., Bielecka M. [w druku]. Wpływ zmiany ustawy o samorządzie gminnym na implementację budżetów obywatelskich w miastach wojewódzkich Polski. Studia Regionalne i Lokalne $1(83)$.

Kociuba D., Lubaś M. (red.). 2018. Atlas ruchu rowerowego w Świdniku. Lublin: Polihymnia.

Kopta T. 2010. Ruch rowerowy w Polsce na tle innych krajów UE. Transport Miejski i Regionalny $3,32-36$.

Lubelska Grupa Badawcza. 2022. Raport z konsultacji. Lubelski Rower Miejski. Lublin.

Lublin Przyjazny Rowerzystom. 2019. Pobrane z: https://lublin.eu/gfx/lublin/userfiles/_public/lublin/przestrzen_miejska/lublin_przyjazny_rowrzystom/poradnik_lublin_przyjazny_rowerzystom.pdf

Łastowska A., Bryniarska Z. 2015. Analiza funkcjonowania wypożyczalni rowerów miejskich w Krakowie. Transport Miejski i Regionalny 3, 30-35.

Mroczek M. 2018. Infrastruktura rowerowa w budżecie obywatelskim miasta Łodzi. Autobusy: technika, eksploatacja, systemy transportowe 19(11), 22-29. https://doi.org/10.24136/ atest.2018.341 
Pala J. 2013. Miasta - ewolucja i środowisko. W: Techniczne problemy zrównoważonego rozwoju miast. Zagadnienia transportu i energetyki (s. 79-87). Warszawa: Oficyna Wydawnicza Wyższej Szkoły Ekologii i Zarządzania w Warszawie.

Postaw na rower - Podręcznik projektowania przyjaznej dla rowerów infrastruktury. 1999. Kraków: C.R.O.W., Zarząd Główny Polskiego Klubu Ekologicznego.

Przygodzki Z., Sokołowicz M. 2016. Logistyka miejska i transport zrównoważony. W: A. Nowakowska (red.), Ekomiasto \& Gospodarka. Zrównoważony, inteligentny i partycypacyjny rozwój miasta (s. 95-122). Łódź: Wydawnictwo UŁ.

Rakower R., Łabędzki J., Gadziński J. 2011. Konkurencyjność ruchu rowerowego w przestrzeni miejskiej, Transport Miejski i Regionalny 2, 31-38.

Senetra A. 2010. Infrastruktura rowerowa w strukturach zurbanizowanych w świetle badań sondażowych i przepisów prawa. Problemy Rozwoju Miast 7(4), 55-67.

Stępień-Słodkowska M., Ustianowski P., Krajewska-Pędzik A., 2017. Bike S Szczeciński Rower Miejski jako przedsięwzięcie prowadzące do wzrostu jakości życia mieszkańców, Handel Wewnętrzny II,4(369), 233-242.

Stowarzyszenie Akcja Miasto. 2016. Badania natężenia ruchu rowerowego. Wrocław: Urząd Miasta we Wrocławiu.

Strategia realizacji systemu dróg rowerowych $w$ mieście Lublin wraz z ocena oddziaływania na środowisko. 2014. Lublin: TransEko.

Urbanyi-Popiołek I. 2013. Ekonomiczne i organizacyjne aspekty transportu. Bydgoszcz: Wydawnictwo Uczelniane Wyższej Szkoły Gospodarki w Bydgoszczy.

Urząd Statystyczny w Krakowie. 2019. Rocznik Statystyczny Krakowa. Kraków.

Wiącek A., Gorczyca K. 2013. Lublin Rowerem - przewodnik miejskiego rowerzysty. Lublin: Towarzystwo dla Natury i Człowieka.

Wolek C. 2010. Kształtowanie systemu ruchu rowerowego na przykładzie Wrocławia. Transport Miejski i Regionalny 11, 35-39.

Zdanowska A., Bojke I. 2017. System Roweru Metropolitalnego jako przyjazne środowisku rozwiązanie transportowe na terenie Trójmiasta. Transport Miejski i Regionalny 3, 29-33.

\section{Akty prawa miejscowego}

Uchwała nr LXX/468/93 Rady Miasta Krakowa z dnia 8 stycznia 1993 r. w sprawie przyjęcia zasad polityki transportowej dla Krakowa.

Uchwała nr CIX/1493/10 Rady Miasta Krakowa z dnia 22 września 2010 r. w sprawie przyjęcia „Programu Inwestycji - Studium Podstawowych Tras Rowerowych”.

Uchwała nr 224/XIV/2011 Rady Miasta Lublin z dnia 20 października 2011 r. w sprawie przyjęcia „Polityki Rowerowej Miasta Lublin”.

Uchwała nr 260/XV/2011 Rady Miasta Lublin z dnia 24 listopada 2011 r. w sprawie przyjęcia „Koncepcji rozwoju komunikacji rowerowej w mieście Lublin".

Uchwała nr XLVII/848/16 Rady Miasta Krakowa z dnia 8 czerwca 2016 r. w sprawie przyjęcia Polityki transportowej dla Miasta Krakowa na lata 2016-2025.

Zarządzenie nr 3113/2018 Prezydenta Miasta Krakowa z dnia 15 listopada 2018 r. w sprawie wprowadzenia „Standardów technicznych i wykonawczych dla infrastruktury rowerowej Miasta Krakowa".

\section{Akty prawne}

Obwieszczenie Ministra Infrastruktury z dnia 9 września 2019 r. w sprawie ogłoszenia jednolitego tekstu rozporządzenia Ministra Infrastruktury w sprawie szczegółowych warunków 
technicznych dla znaków i sygnałów drogowych oraz urządzeń bezpieczeństwa ruchu drogowego i warunków ich umieszczania na drogach (Dz.U. 2019, poz. 2311).

Rozporządzenie Ministra Transportu i Gospodarki Wodnej z dnia 2 marca 1999 r. w sprawie warunków technicznych, jakim powinny odpowiadać drogi publiczne i ich usytuowanie (Dz.U. nr 43, poz. 430).

Rozporządzenie Ministra Infrastruktury z dnia 3 lipca 2003 r. w sprawie szczegółowych warunków technicznych dla znaków i sygnałów drogowych oraz urządzeń bezpieczeństwa ruchu drogowego i warunków ich umieszczania na drogach (Dz.U. nr 220, poz. 2181).

Ustawa z dnia 20 czerwca 1997 r. - Prawo o ruchu drogowym (Dz.U. nr 98, poz. 602 ze zm.).

\section{Strony internetowe}

http://bip.krakow.pl/?mmi=509

http://ibikekrakow.com/mapa

http://kmr.org.pl

https://lubelskirower.pl

https://lubelskirower.pl/mapa-stacji

http://lublin.eu/finanse-i-majatek/sprawozdanie-z-wykonania-budzetu-miasta

https://lublin.eu/lublin/przestrzen-miejska/aktualnosci/lublin-przyjazny-rowerzystom,95,2133,1. html

http://mirl.info.pl/mapa

https://mirl.info.pl/publications

https://mirl.info.pl/publications/statLRM

https://mirl.info.pl/publications/statLRM/2019

https://mirl.info.pl/publications/statLRM/2019/heat_map

https://mobilityweek.eu/home

http://mobilnykrakow.pl

http://mobilnykrakow.pl/mapy/mapa-rowerowa

http://mobilnykrakow.pl/rowery/\#edukacja

http://otwartyplan.org.pl

https://pl-pl.facebook.com/pg/lublinrowerem/events

https://porozumienierowerowe.pl

http://rowery.zikit.pl

http://swidnikmiastodlarowerow.pl

https://wavelo.pl

http://welocypedlubelski.pl/historia

www.cargo.lublinrowerem.pl 